\title{
Non-Bank Investors and Loan Renegotiations
}

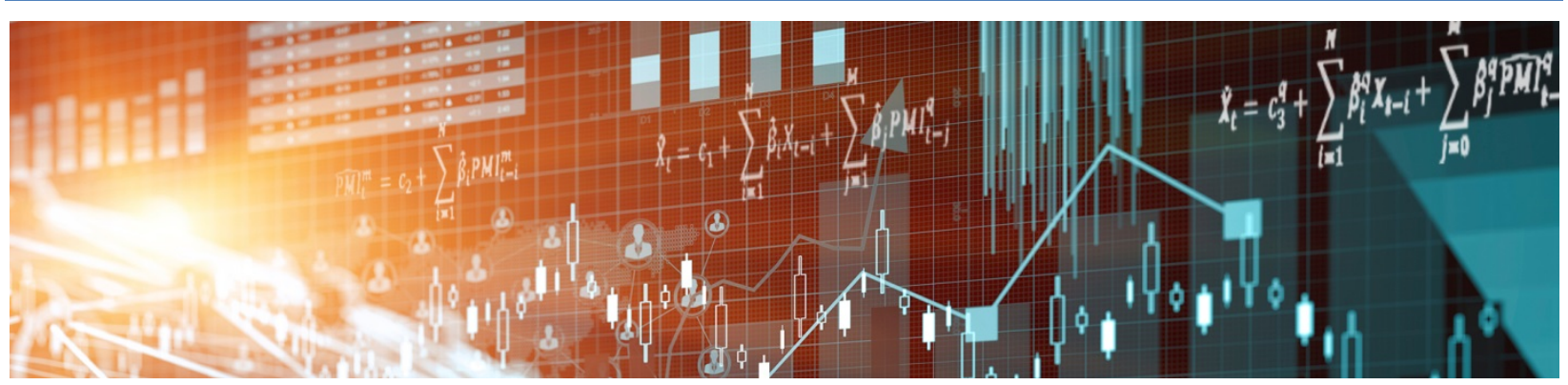

by Teodora Paligorova and João A. C. Santos 
Bank of Canada Staff Working Paper 2016-60

December 2016

\title{
Non-Bank Investors and Loan Renegotiations
}

\author{
by
}

Teodoara Paligorova ${ }^{1}$ and João A. C. Santos ${ }^{2}$

1Financial Stability Department

Bank of Canada

Ottawa, Ontario, Canada K1A 0G9

tpaligorova@bankofcanada.ca

2Federal Reserve Bank of New York

New York, New York, 10045

joao.santos@ny.frb.org 


\section{Acknowledgements}

The authors thank Jason Allen, Andra Ghent, Kim Huynh, Charles Kahn, David Martinez-Miera, Robert Marquez, Mitchell Berlin, Greg Nini, Steven Ongena, Enrique Schroth, Sascha Steffen, Larry Wall and participants of the EuroFIT Research Workshop on Corporate Loans, the University of Amsterdam, the Federal Reserve Bank of Atlanta, the University of Gothenburg, the 2015 Baffi Centre Conference, and the 2016 Chicago Financial Institutions Conference for valuable comments. We thank Vitaly Bord for outstanding research assistance. 


\begin{abstract}
We document that the structure of syndicates affects loan renegotiations. Lead banks with large retained shares have positive effects on renegotiations. In contrast, more diverse syndicates deter renegotiations, but only for credit lines. The former result can be explained with coordination theories. The puzzling effect of syndicate diversity in term loan renegotiations derives from the growth of collateralized loan obligations (CLOs) in the syndicated loan market and the coordination between these vehicles and lead banks. CLOs that have a relationship with the lead bank of the renegotiated loan are strong supporters of amount-increase renegotiations, arguably because this gives them access to attractive investments. Related CLOs fund not only their portion of the loan increase, but also the portion that was supposed to be funded by the lead bank. Our findings highlight the previously unrecognized role of the growing presence of non-bank lenders in corporate lending.
\end{abstract}

Bank topic(s): Financial institutions; Financial system regulation and policies JEL code(s): G21; G23

\title{
Résumé
}

Nous montrons que la structure des syndicats financiers influe fortement sur la renégociation des emprunts. Les syndicataires chefs de file qui conservent d'importantes participations ont une incidence positive sur les renégociations. À l'inverse, des syndicats diversifiés rendent la renégociation moins probable, mais uniquement lorsqu'elle concerne des lignes de crédit. L'influence des syndicataires s'explique par la théorie des problèmes de coordination. L'effet étonnant de la diversité des syndicats financiers sur la renégociation des emprunts à terme trouve son origine dans la croissance des fonds de titres adossés à des prêts sur le marché des crédits consortiaux et dans la coordination entre ces véhicules et les syndicataires chefs de file. Lorsqu'ils ont une relation avec les syndicataires chefs de file, les fonds sont plus nettement favorables à une augmentation du montant des crédits renégociés, sans doute parce que cette hausse leur offre des possibilités de placement intéressantes. Ces fonds financent non seulement leur part de la hausse des crédits, mais aussi la part que le syndicataire chef de file est censé assumer. Nos constats mettent en évidence le rôle jusqu'alors méconnu des prêteurs non bancaires, qui découle de leur présence grandissante sur le marché du crédit aux grandes entreprises.

Sujet(s) : Institutions financières; Réglementation et politiques relatives au système financier

Code(s) JEL : G21; G23 


\section{Non-Technical Summary}

The syndicated loan market is a useful laboratory for exploring the economics of multiple lenders. While this market was dominated by banks in the 1990s, many non-bank lenders, such as collateralized loan obligations (CLOs), pension funds, hedge funds, loan mutual funds, finance companies and private equity firms, have invested in syndicated loans since then. This development may impair firms' ability to renegotiate their loans, which is relatively easy with a single lender but may not be so with multiple lenders. Since the set of non-bank lenders is highly heterogenous in terms of business objectives and exposures to the borrowers, lenders may find it hard to coordinate, and this could become a barrier to renegotiations.

Our data on US loans are unique in addressing the issue of whether non-bank lenders impede renegotiations over a 20 -year period. Using the information about the types of nonbank lenders and their exposures to the borrower, we find that the diversity of the syndicate impedes renegotiations in credit lines but surprisingly facilitates renegotiations in term loans. The latter result is driven by the massive entry of CLOs in the term loan market. CLOs have incentives to support amount-increase renegotiations because this allows them to fund new loan investments. Interestingly, the lead banks manage to sell a portion of their exposures after the approval of the renegotiation. An important mechanism that drives this interaction between CLOs and lead banks is their relationship through underwriting services. As an underwriter of the CLO deal, the lead bank likely finds it easier to sell its shares to the CLO. This result sheds some new light on the way banks interact with the shadow banking sector.

Our result has important policy implications. Since the start of the financial crisis, securitization vehicles were found to impede mortgage foreclosures, which may motivate regulators to alter their incentives to limit the participation of these investors in mortgage funding. Our finding highlights the fact that securitization vehicles behave differently when it comes to loan renegotiations on viable investment projects, suggesting that the behaviour of these vehicles depends of the type of investment. Regulatory efforts should therefore be directed to the type of collateral instead of being applied unilaterally to the entire portfolio of investments. 


\section{Introduction}

Bank loans are considered easier to renegotiate than public debt because they are typically owned by a single bank lender, as opposed to the diffused ownership in the public debt market. However, with the development of the syndicated loan market, banks have begun to retain only a portion of the originated loans, placing the remainder with other institutional investors. ${ }^{1}$ As a result, many non-bank investors, including collateralized loan obligations (CLOs), pension funds, hedge funds, loan mutual funds, finance companies and private equity firms, began to invest in corporate loans. ${ }^{2}$ The growing presence of non-bank investors in loan syndicates not only helped banks expand their lending business, but also may have adversely affected a distinct feature of traditional bank loans - the flexibility to renegotiate their terms. In this paper, we investigate the impact of the loan syndicate structure on renegotiations.

The presence of multiple lenders in a loan syndicate gives rise to coordination problems, which are likely to intensify with the dispersion of investor shares. An increase in investor diversity implies a rise in the number of different business models and objectives (Botlon and Sharfstein (1996), Gilson et al. (1990)). Investor diversity can also lead to a divergence of opinion about the benefit of renegotiations, possibly owing to the degree of information available to different investors. Further, if higher non-bank lender shares are accompanied by lower lead bank retained shares, the latter could have indirect negative effects on loan renegotiations because of weakened incentives to screen and monitor borrowers as well as weaker bargaining power in the (re)negotiation process. Altogether, a high dispersion in loan ownership may be a barrier to renegotiations.

We use the Shared National Credit (SNC) database from 1988 to 2010 to explore the role of loan ownership structure in the renegotiation of privately placed debt outside of financial distress. We use the detailed information about the ownership structure of the loan in terms

\footnotetext{
${ }^{1}$ The US syndicated loan market rose from $\$ 339$ billion in 1988 to $\$ 2.2$ trillion in 2007 , when the market reached its peak. The secondary loan market evolved from a market in which banks participated occasionally, most often by selling loans to other banks, to an active, dealer-driven market where loans are sold and traded much like other debt securities. The volume of loan trading increased from $\$ 8$ billion in 1991 to $\$ 176$ billion in 2005.

${ }^{2}$ From 1988 to 2010, the maximum number of non-bank lenders in term loans had grown from 2 to 10 . Over the same period both the diversity of investors and their market share increased (Figure 1).
} 
of lenders' shares and types throughout the life of the loan to investigate two questions: What is the role of the lead bank share in loan renegotiations? To what extent is the diversity among the non-bank investor shares in the syndicate a barrier to renegotiations? We focus on renegotiations mainly driven by borrowers' needs to increase the size of their loans. In contrast to renegotiations that aim to alter other terms of the loan (i.e., covenants or interest rates), amount-increase renegotiations require investors to provide additional funding and, consequently, increase their exposure to the borrower. Lenders may be motivated to decline such renegotiation requests because of funding constraints.

Consistent with theory, we find that high retained shares by the lead bank play a positive role in renegotiations. One potential concern with this result is that renegotiation outcomes and lead bank shares evolve endogenously. Theoretically, lead shares can either increase (e.g., Botlon and Sharfstein (1996)) or decrease (e.g., Garleanu and Zwiebel (2009)) in expectation of a renegotiation. In our data, however, we do not find that lead banks adjust their loan shares when a renegotiation is expected. Also, our finding continues to hold when we restrict our analysis to a set of renegotiations that are likely unexpected by the lead bank.

Our results show that investor diversity, captured in several different ways, plays a role in renegotiations but the nature of the effect varies with the credit type. Higher nonbank investor diversity is detrimental to credit line renegotiations but is helpful to borrowers who wish to renegotiate their term loans. For credit lines, the result is consistent with the theoretical arguments about coordination problems, as discussed above. Given that banks are the major providers of funding for credit lines, the presence of non-bank lenders, for whom the provision of liquidity poses a bigger challenge, hampers borrowers' efforts to renegotiate their credit lines. Our result for term loans is therefore puzzling not only because it appears to run counter theory predictions, but also because non-bank investor diversity is much higher in term loan syndicates than in credit line syndicates.

We find that the explanation to this puzzle is related to the sizable entry of CLOs in the term loan market after 2000, accompanied with a complex form of coordination between these vehicles and the lead bank of the loan under renegotiation. The positive effect of investor diversity on term loan renegotiations holds only after 2000, and CLOs are the only non-bank 
lender type that supports renegotiations. Further, we find that this result is driven by those CLOs that have a relationship with the lead bank of the loan by virtue of having used that bank to underwrite the CLO deal. This relationship appears to be valuable to both parties because it allows the lead bank to support the renegotiation without funding the loan increase and consequently lowering its share of the loan after the renegotiation. Related CLOs, in turn, step in and fund the portion of the loan increase they are responsible for, together with the portion of the increase that should have been funded by the lead bank thereby increasing their share in the loan.

The substitution between the lead bank and its related CLOs is feasible because renegotiations typically occur between the third and fifth year of the loan life, when information asymmetry between the syndicate members and the borrower has likely decreased significantly and the monitoring role of the lead bank is less critical. A decrease in the retained share will likely be valuable for the lead bank because it can save on capital, which can be potentially used to originate new loans. It will also likely be valuable for CLOs - as actively managed pools of collateral, they are typically interested in increasing their leveraged-loan investments. Our findings are robust. Given the detailed information in our data set, we can control for observable loan and lead bank characteristics that may be correlated with syndicate structure and loan renegotiations. Nevertheless, there could be concerns regarding the endogeneity between the syndicate structure and loan renegotiations. For instance, the lead share and non-bank investor diversity in syndicates may be driven by a common unobserved factor that is correlated with the likelihood of renegotiation. In an attempt to address this concern, we estimate instrumental variables regressions, whereby the instrument for lead bank shares is the concentration of the entire corporate loan portfolio of the lead bank in a given year. This variable affects renegotiations only through the lead share. The instruments for the syndicate structure are the co-movements of shares of different pairs of lenders within a given year (e.g., the correlation of shares across all CLO and mutual fund deals). The intuition is that syndicate diversity is driven by a host of factors, such as the similarity (or the lack of it) of business models across lenders and common investor-specific risk exposure that will make investors choose similar (or different) strategies with respect to their loan investments. These developments 
should not be correlated with a borrower's decision to renegotiate but rather should reflect a broader investment agenda of non-bank lenders that does not coincide with the likelihood to renegotiate.

We also investigate the role of the syndicate structure in credit line renegotiations that are likely unexpected for the lender and hard to predict based on observable data. To this end, we consider only the subset of credit line renegotiations that do not appear to be critical to borrowers in the sense that they did not need them to support the drawdowns they do the year after the renegotiation. In other words, they could have still drawn down the same amount had they not renegotiated their credit lines. Finally, to account for unobservable credit quality, we estimate loan-logit fixed effects regressions. Our findings about the relationship between the syndicate structure and loan renegotiations continue to hold in all of these robustness tests.

Our paper contributes to three strands of the literature. We add to the recent literature on the role of securitization in the renegotiation of distressed loans or mortgages. For example, Demiroglu and James (2015) show that CLOs deter the renegotiation of troubled loans. Similar conclusions come from mortgage renegotiations found in Agarwal et al. (2011). Unlike these studies, we highlight that CLOs, in particular those related to the lead bank of the loan under renegotiation, are supportive of amount-increase renegotiations because they have an incentive to increase their investments. Related CLOs increase their loan share by funding not only the portion of the loan increase they are responsible for (by virtue of their loan share), but also the portion that the lead bank was responsible for.

Evidence that CLOs that use the lead bank as an underwriter for the CLO deal favor renegotiations highlights another benefit of combining lending with underwriting services. Previous studies have documented the benefits of combining lending with bond underwriting services (e.g., Drucker and Puri (2005)). Our results suggest that it is also beneficial to combine lending with CLO underwriting services - it motivates the lead bank to support amount-increase renegotiations without funding the loan increase and it provides CLOs with an opportunity to make additional investments in loans they are already familiar with.

Finally, our paper is related to an existing set of studies of the drivers of loan renegotiations (Roberts and Sufi (2009), Roberts (2015) and Mian and Santos (2011)). Roberts and Sufi 
(2009) rely on a cross-section of loans from DealScan and SEC filings to establish a few stylized facts about loan renegotiations - they result in large changes to the amount, maturity, and pricing of the contract, and they are mostly driven by improvements in credit quality and credit market conditions. Roberts (2015) examines the determinants of renegotiation throughout the life of the loan. The results show that loans for which the initial terms are restrictive, possibly because of high information asymmetries, are more likely to be renegotiated. Mian and Santos (2011) rely on the SNC data and document that more creditworthy firms refinance early when credit conditions are good in order to prolong the effective maturity of their loans and hedge against market-wide adverse changes of the cost of credit. We complement these studies by documenting the role of the syndicate structure on loan renegotiations.

The rest of the paper is structured as follows. Section 2 discusses relevant theoretical background. Section 3 outlines our methodology, data sources, sample characteristics. Section 4 reports results on the importance of lead banks shares and non-bank investor diversity on renegotiation prospects. Section 5 examines the roles of different lender types. Section 6 presents the results of a set of robustness tests, and Section 7 concludes the paper.

\section{Theoretical Motivation and Hypotheses}

The scope for renegotiations arises mainly because of incomplete contracts whose terms can be changed upon the arrival of new information (e.g., Hart and Moore (1988)). When a borrower's financial condition improves, restrictive initial terms can be renegotiated by bargaining for reductions in interest rates, covenant changes, and/or increases of available credit. ${ }^{3}$ However, coordination problems among lenders can block loan renegotiations because they often require unanimous consent by all loan investors.

The implications of incomplete contracts for the likelihood of renegotiations depend on the degree of information asymmetry between borrowers and lenders, moral hazard problems,

\footnotetext{
${ }^{3}$ Renegotiations can be valuable for borrowers because they may lead to fewer defaults (Berlin and Mester (1992)). Based on a structural model that takes into account renegotiations in and outside of distress, Arnold and Westermann (2016) find that debt renegotiations increase firm value by $3.8 \%$. However, it is also possible that if the lender cannot credibly threaten to liquidate the firm and a renegotiation is ex ante easy, the borrower may take excessive risks and miss repaying the loan in full (Botlon and Sharfstein (1996)).
} 
and the cost of renegotiation. Loan contracts can be designed ex ante with these factors taken into account to either impede or facilitate future renegotiations. Garleanu and Zwiebel (2009) show that the initial allocation of control rights between borrowers and lenders is irrelevant under symmetric information and costless renegotiations, and renegotiations occur frequently to guarantee efficient investment. However, if the lenders are relatively less informed about the borrower, then stronger rights (i.e., tighter covenants that effectively give the lender veto power over future investments) are granted to the lender. In this case, the uninformed party gives up its rights through renegotiations. Dessin (2005) shows that a better informed borrower yields control rights to the less-informed lender.

To formulate our two hypotheses, we rely on these insights from the incomplete contract theory. Our first hypothesis pertains to the role of the lead bank. We expect high lead bank shares at the time of renegotiation to be positively related to renegotiation outcomes. High lead bank share ensures that lead banks have incentives to monitor the borrower and also have strong bargaining power in the renegotiation process. It is also possible that lead bank shares and renegotiation prospects are correlated at the time of loan origination. In addition to constructing the deal and using its retained share to signal monitoring and screening incentives to other lenders, the lead arranger may be guided by renegotiation considerations. ${ }^{4}$ The lead bank can acquire a larger share at origination because they want to support future high-quality renegotiations, which induces endogeneity between the lead bank share and the likelihood of renegotiation.

Our second hypothesis is about the impact of the diversity of investors on loan renegotiations. We expect more diverse syndicates with respect to non-bank lender shares and/or non-bank lender types to deter renegotiations. The presence of multiple lenders may give rise to coordination problems, which is likely to intensify with the heterogeneity of loan investors. An increase in investor diversity implies a rise in the number of different business models and objectives. Investor diversity can also foster the divergence of opinion about the benefit of rene-

\footnotetext{
${ }^{4}$ See Gorton and Pennacchi (1995) for a model on the impact of lead bank share on monitoring incentives. For studies that argue that lead banks use retained loan share to align their incentives with those of syndicate participants and commit to future monitoring, see Sufi (2007) and Ivashina (2009).
} 
gotiations stemming from limited information available to different investors. This suggests that loans owned by more diverse syndicates will be harder to renegotiate. However, the syndicate structure and the prospect of a renegotiation may be related not only at the time of the renegotiation but also at the time of loan origination (Botlon and Sharfstein (1996)). Similar to the lead bank share, syndicate structure and renegotiations may evolve endogenously.

Overall, we expect high lead shares to facilitate renegotiations, while more pronounced syndicate diversity to be a barrier to renegotiations. Theoretically, the lead bank share and syndicate diversity may be endogenous both at the time of loan origination and/or at the time of loan renegotiation.

\section{Methodology, Data and Sample Characteristics}

In this section, we present the methodology and the data we use to investigate our hypotheses. We also provide descriptive characteristics of our sample.

\subsection{Methodology}

We rely on the following specification to investigate the impact of the syndicate structure on loan renegotiations:

$$
\begin{aligned}
\operatorname{Pr}\left(\text { Renegotiate }_{l, b, t}\right) & =\operatorname{Logit}\left(\alpha L E A D_{l, b, t-1}+\beta D I V E R S I T Y_{l, t-1}\right. \\
& \left.+\gamma X_{l, t}+\theta Z_{b, t-1}+\text { TimeEffects }\right) .
\end{aligned}
$$

We use maximum likelihood to estimate the logitstic function of the probability to renegotiate a loan in a given year. Renegotiate $l_{l, b, t}$ takes the value one if loan $l$ with a lead arranger $b$ is renegotiated in year $t$, and zero otherwise. We estimate equation (1) separately for term loans and credit lines because the syndicate structure of term loans is quite different from that of credit lines. We focus on amount-increase renegotiations, as opposed to other non-price terms, because they require either a proportional increase in relative shares of existing investors or a 
redistribution of loan investments across new or existing lenders. ${ }^{5}$ A potential concern with these renegotiations is that sometimes borrowers buy the so-called accordion clause, which allows them to automatically increase the size of their loans under an existing loan facility up to a specified amount. ${ }^{6}$ To reduce concerns that our definition of renegotiations also includes loan increases because of accordion clauses, we consider only renegotiations in which the size of the loan increases and and its maturity changes. Typically, if more than one loan term is changed, it is the result of a renegotiation rather than a pre-approved agreement arranged when the loan was originated.

The two key variables in our model of renegotiations are LEAD and DIVERSITY. $L E A D$ measures the lagged retained share of the lead bank. Our conjecture is that a large lead bank share facilitates renegotiations. To the extent that lead banks' incentives to monitor depend on their loan exposures, larger retained shares will likely facilitate renegotiations because the lead bank would be better informed about the borrower's funding needs and business prospects. In addition, larger lead bank share may facilitate renegotiations because it adds credibility to the role of the lead bank in the renegotiation process, which will likely influence the renegotiation decision of the remaining syndicate members.

DIVERSITY attempts to capture the importance of non-bank lender diversity on renegotiations prospects. Diverse syndicates will likely hamper renegotiations. Diversity indicates differences in the business models of investors and, therefore, a higher likelihood of not being able to coordinate and accommodate borrowers' requests to change the loan terms. It also likely implies different incentives for the acquisition of borrower information, which may further increase the divergence of opinions about the merits of the renegotiation. We consider three measures of investor diversity in loan syndicates. The first measure, \# Non-bank types, is the number of different non-bank investor types such as CLOs, finance companies, funds

\footnotetext{
${ }^{5}$ We omit renegotiations related to amount decreases as they are indistinguishable from down payments in the data.

${ }^{6}$ The accordion feature in loan agreements allows the borrower to add a new term loan tranche or increase the revolving credit loan commitments under an existing loan facility up to a specified amount under certain terms and conditions. The advantage of this feature is that the increase in the loan amount is pre-approved by the lenders so that the borrower does not have to get the lenders' consent if it increases the loan facility at a later date. The interest, maturity, and other terms of an increase will be identical to those applicable to the existing facility.
} 
(loan mutual funds, hedge funds and pension funds), brokers, and insurance companies. ${ }^{7}$ All else equal, we expect renegotiations to be less prevalent if the syndicate has many non-bank lender types.

The second measure, Non-bank share, is the total share of non-bank investors. ${ }^{8}$ While the variable Non-bank share treats non-bank investors as a collective group relative to lead banks, the variable \# Non-bank types proxies for the diversity of lender types, hence business models. Although these two variables are positively correlated, there is still enough crosssectional variability, whereby some syndicates have large non-bank shares with a few non-bank lender types, and vice versa.

The third measure, Non-bank HHI, is defined as the Herfindahl-Hirschman index (HHI) of the sum of the squared non-bank shares for each lender type. The shares are computed as the ratio of loan amount for each lender type divided by loan amounts funded by nonbanks. This measure gauges the degree of concentration of non-bank shares. We expect more concentrated syndicates to facilitate renegotiations because coordination problems are less pronounced. However, this may not be the case if the largest non-bank lender(s) do not favour renegotiations. We view our three measures as complementary measures that account for different aspects of syndicate diversity.

We control for loan and lead bank specific factors in the logit regression. Starting with the set of loan-specific controls, $X_{l, t}$, we account for the initial amount of the loan ( Ln initial loan amount) because the starting terms of the contract may affect the willingness to request a renegotiation. We include the internal loan rating (Loan rating) assigned by the lead bank and expect that less risky loans are easier to renegotiate. Additionally, when we investigate the renegotiation of credit lines, we use $C L$ drawdown ratio to control for the drawn-down fraction of credit lines - the higher the draw-down rate, the more likely the renegotiation request is.

We account for the loan purpose with a set of three dummy variables that take one if the loan is originated to fund working capital, mergers and acquisitions, or real estate activities.

\footnotetext{
${ }^{7}$ An alternative measure is the total number of non-bank lenders, which has 0.7 correlation with the number of non-bank investor types.

${ }^{8}$ Note that in addition to the lead bank and non-bank investors there are also bank investors, whose retained shares are omitted from the logit regression to avoid collinearity.
} 
These three categories comprise the top three loan purposes. Some loan purposes may impose higher funding needs and thus be more prone to renegotiations. We include a set of dummy variables, Loan age, to account for the age of the loan since borrowers may be more likely to renegotiate as the loan approaches maturity. Lastly, we control for the number of years till the loan matures, Maturity left. Typically, loans are renegotiated relatively early in their life time, from three to five years. We complement our set of loan-specific controls with a dummy variable which takes the value one if the borrower has a rating from a credit rating agency, Borrower rating. Because there is information about these firms publicly available, loan renegotiations should be easier.

Our last set of controls, $Z_{b, t-1}$, accounts for the financial condition of the lead bank. To the extent that the retained share by the lead bank is correlated with bank financial conditions, it is important to control for bank characteristics. For that reason, we control for the ratio of bank equity to total assets, Capital bk, and for the ratio of the bank's cash and marketable securities to total assets, Liquidity bk. Well-capitalized and liquid banks are better positioned to meet renegotiation requests. We also control for the ratio of deposits to total assets, Deposits bk, and for the bank's return on assets, Profitability bk. Deposits continue to be the main source of bank funding, and more profitable banks will likely find it easier to approve renegotiations. Lastly, we control for the log of a bank's total assets, L assets bk. Larger banks usually have access to more funding sources and tend to have a larger share of the syndicated loan market, which makes them more influential in the renegotiation process.

We include year fixed effects to absorb time heterogeneity at the yearly level. The year fixed effects capture all macroeconomic effects at the yearly level, which is the frequency of our data. The standard errors are clustered and robust at the loan level.

\subsection{Data}

The main data source for this project is the Shared National Credit (SNC) Program run by the Federal Deposit Insurance Corporation, the Federal Reserve Board, and the Office of the Comptroller of the Currency. The SNC Program gathers confidential information on syndicated loans that exceed $\$ 20$ million and are held by three or more federally supervised institutions 
at the end of the year. ${ }^{9}$ The program reports the identity of the borrower, the type of credit (e.g., term loan, credit line), its purpose (e.g., working capital, mergers and acquisitions), the outstanding amount, the origination and maturity dates, and the internal bank rating. In addition, the program reports information on the lead arranger and syndicate participants, including their identity and the share of the credit that they hold.

The SNC program contains all of this information at the end of each calender year throughout the life of the credit. This gives us the opportunity to identify instances of credit renegotiations and to investigate the impact of the loan syndicate structure on renegotiation outcomes. Further, since the program reports information over the last two decades, a period in which syndicated lending experienced a rapid expansion with the growth of the originateto-distribute model in corporate lending. This helps us identify the importance of lenders' diversity in renegotiation outcomes.

Thus far, it has been difficult to investigate lenders' roles in renegotiations because of the lack of data. DealScan includes information only at the time of the loan origination and, even then, it has very limited information on loan shares. For example, information on the lead bank share is missing for about $70 \%$ of DealScan credits and information on the shares of syndicate participants is even more sparse. The Loan Syndications and Trading Association database contains information on loans traded in the secondary market, but it has no information about the identity of the seller(s) or buyer(s), ruling out its use to close the information gaps in DealScan. SEC filings, which have been used in loan renegotiation studies, are valuable to complement the information reported in DealScan with regard to the nature of the renegotiation, but they too do not contain information on lenders' retained shares.

We complement the SNC data with information from Moody's Structured Finance Default Risk Service Database, the Intex Agency CDO deal library, Compustat, Standard and Poor's Capital IQ and from Call Reports. Moody's and Intex's databases have information on structured finance products, including the size, origination date, and names. We rely on these data sources to identify CLOs among the syndicate participants reported in the SNC

\footnotetext{
${ }^{9}$ The confidential data were processed solely within the Federal Reserve System for the analysis presented in this paper.
} 
program. We also use these data to identify those CLOs with managers that are affiliated with banks. We use Capital IQ database to identify private equity firms, hedge funds, and mutual funds among the syndicate participants. Finally, we use Call Reports to gather bank-level information for the lead arrangers in the syndicates.

\subsection{Sample characteristics}

To form a loan-year panel data set from 1988 to 2010, we follow each loan from the year of origination or when it first appears in the SNC database (for loans originated before 1988) until the year of maturity or the end of the sample period (for loans with maturity dates after 2010). Our analysis sample contains information for 92,818 loan observations taken out by 15,730 firms.

Table 1 reports information on the characteristics of loans and syndicate lenders. The lead bank share is $23.9 \%$ on average, with similar mean values for term loans and credit lines. Non-bank lenders together own on average $11 \%$ of each loan, but there is a substantial difference between credit lines and term loans (9.7\% and $24.5 \%$, respectively). The average number of non-bank types is 0.82 for credit lines and 1.75 for term loans. Term loan syndicates are more concentrated than credit line syndicates (in terms of the HHI of non-bank shares), and they tend to be more diverse than credit line syndicates (in terms of the number of different investor types). We find that $7.3 \%$ of the loans undergo at least one renegotiation, with a higher frequency for credit lines than term loans. When the first loan year in which, by definition, the loan cannot be renegotiated is excluded, the percentage of loans that are renegotiated at least once goes up to $11 \%$.

The SNC data report information on the portion of the credit line that the borrower has used i.e., the ratio between the amount that has been drawn down and the total amount of the credit line (CL drawdown ratio). The average draw-down rate in our sample is $40.6 \%$. With regard to the ratings assigned by banks, $86 \%$ of the loans are rated investment grade (Loan rating). ${ }^{10}$

\footnotetext{
${ }^{10}$ In the SNC program, loans are rated using the following ratings: pass, special mention, substandard, doubtful and loss. Each of these ratings can take values between 0 and 100, and they indicate the percentage
} 
The middle panel of Table 1 reports summary statistics for non-bank investors in loan syndicates. Finance companies, followed by funds (mutual, hedge and pension funds), and CLOs are the non-bank investors that appear most often in loan syndicates. This is true both in term loans and credit lines. However, it is interesting to note that while finance companies have on average larger investments in credit lines than in term loans (14.0\% vs. $12.8 \%$ ), the opposite holds true for funds (12.9\% vs. 20.4\%) and CLOs (16.6\% vs. 26.0\%), probably because the liquidity risk of credit lines poses bigger challenges for funds and CLOs.

The third panel in Table 1 reports balance-sheet summary statistics for lead banks. To capture any potential effects that may arise from ownership transfers between entities of the same holding company, we measure these controls at the holding company level. For ease of exposition, we continue to refer to these as bank controls. The sample of lead banks that are active in the syndicated loan market has mean log of assets of 18.3, an average equity-to-assets ratio of $5.9 \%$, and average deposit-to-assets ratio of $36.7 \%$. We also winsorize the bank controls at the upper and lower one-percentile levels.

Figures 1 and 2 show that while banks continue to dominate credit lines, over time non-bank lenders, such as CLOs and mutual funds, have increasingly funded a larger fraction of term loans. ${ }^{11}$ The growing presence of non-bank lenders in term loan syndicates has had a wide range of implications. As we can see from the right panel of Table 1, which compares term loan syndicates before and after 2000, the portion of the term loans owned by non-banks went up as did the number of non-bank investor types after 2000. In contrast, the share of the loans owned by lead banks declined significantly from an average of $27.1 \%$ in the pre-2000 years to an average of $19.9 \%$ in the post-2000 years.

\section{Syndicate Structure and Loan Renegotiations}

Table 2 reports the results of the impact of lead bank shares and the diversity of the syndicate on renegotiation prospects, separately for term loans and credit lines. This split is motivated

of the loan receiving that rating. Consequently, loans may have different portions with different ratings.

${ }^{11}$ See Bord and Santos (2012) for a detailed analysis of the evolution of lender shares over time. 
by the evidence we presented in the previous section showing that the syndicate structures of credit lines and term loans are markedly different. For example, credit lines are predominantly funded by banks, while term loans have increasingly attracted non-bank investors. Non-bank lenders retain on average $9.7 \%$ of credit lines, while their average share is $25 \%$ in the case of term loans. On average, term loans have twice as many non-bank lender types than credit lines. This is consistent with theories that explain why banks are better positioned than non-bank lenders to provide liquidity to corporations by extending credit lines. ${ }^{12}$

The dependent variable is defined as a dummy variable that takes the value one if the loan is renegotiated in a give year and zero otherwise. Columns (1) to (4), Table 2, report results for credit lines while columns (5) to (8) report results for term loans. Starting with column (1), our main coefficient of interest is the estimate on the lead bank's loan share, Lead bank share. Its positive and significant estimate confirms that the likelihood of a renegotiation is higher for credit lines with high lead bank shares. A change in the lead share from the 25 th to the 75 th percentile is associated with a positive change in the predicted probability of renegotiations from $6 \%$ to $10 \%$ (Figure $6 a$ ). ${ }^{13}$ Given that the unconditional likelihood of loan renegotiation is $7.3 \%$, the estimated coefficient has a relatively large impact on the renegotiation prospect.

Columns (2) through (4) investigate the importance of our three measures of investor diversity on renegotiation prospects. In column (2), we control for the total number of nonbank types (\# Non-bank types) in the syndicate. Because different non-bank lender types likely follow different business models, the coordination issues among lenders will be more acute and hence renegotiations less likely. Indeed, our results show that the number of non-bank types in the syndicate has a negative impact on loan renegotiation prospects. A change in the number of non-bank types from the 25th to the 75 th percentile is associated with a decrease in the predicted probability of renegotiations from $8.3 \%$ to $6.8 \%$ (Figure $6 \mathrm{~b}$ ). The magnitude of the

\footnotetext{
${ }^{12}$ Holmström and Tirole (1997) show that banks can insure firms against liquidity shocks that disrupt their investments by offering them credit lines. Kashyap et al. (2002) show that as long as the liquidity needs of depositors and corporations are not correlated, it is advantageous to combine deposit taking with credit line provision because it saves on the costly liquidity buffers that banks need to keep to meet unexpected deposit withdrawals and drawdowns on credit lines.

${ }^{13}$ The 25 th and 75 th percentile of the lead bank share distribution for credit lines correspond to $10 \%$ and $40 \%$, respectively. All other covariates are held fixed at their mean values.
} 
lead share estimate in this specification is not changed compared to column (1), implying that both lead banks and non-bank lenders matter independently for renegotiations. In terms of relative contribution, the positive impact of the lead bank share is stronger than the negative impact of the non-bank types.

In column (3), we control for the concentration of non-bank investors as determined by their loan shares. The positive estimate of Non-bank HHI confirms that high concentration among non-bank lenders in the syndicate is supportive of renegotiations. Given that more concentration among non-bank investors likely implies less diversity, this result lends support to our previous finding that syndicate diversity adversely affects the loan renegotiation prospects.

In column (4), we control for the sum of all non-bank shares. Our results show that if the non-bank share changes from the 25 th to the 75 th percentile, the likelihood of a renegotiation drops from $8.2 \%$ to $7.6 \%$ (Figure $6 \mathrm{~d}$ ). This finding adds further support to our assertion that the presence of non-bank investors, and the diversity among these investors, reduces the ability of borrowers to successfully renegotiate their loans.

Other controls reported in columns (1) to (4) are generally consistent with expectations. Investment-grade credit lines as well as credit lines with a higher drawdown rate are more likely to be successfully renegotiated. The same applies to credit lines that are not close to the maturity date. More transparent borrowers, i.e., borrowers with a credit rating are also more likely to renegotiate their loans compared with unrated ones. Banks that rely more on stable deposit funding are more likely to allow credit line renegotiations. More profitable banks seem to avoid renegotiations, presumably because they have better investment opportunities.

Columns (5) through (8) report a similar set of tests using only the sample of term loans. In column (5), the estimate on the lead share implies that a change from the 25th to the 75 th percentile leads to an increase in the renegotiation probability from $3.2 \%$ to $4.5 \%$. Figures $6(\mathrm{e})$ to $(\mathrm{h})$ show the margin plots for the variables of interest, keeping all other controls at their mean values. Lead bank share seems to have a weaker impact on term loans than on credit lines renegotiations. More surprisingly, all of our proxies for non-bank investor diversity indicate the opposite effect in term loans. More non-bank lender types (column (6)) and larger investments by non-banks (column (8)) are helpful for the renegotiation of term loans. 
Similarly, more concentrated syndicates in terms of non-bank lender shares seem to deter term loan renegotiations (column (7)), which is the opposite for credit lines. All other controls have similar impacts as for credit lines, except for the strong impact of Ln initial loan amount: the higher the initial loan amount is, the less likely the renegotiation.

The effect of non-bank diversity on term loan renegotiations is puzzling. Non-bank lenders comprise a heterogeneous pool of investors with different business models and incentives to support renegotiations. As discussed in Section 2, stronger diversity may be a barrier to renegotiations. This is indeed the case in credit lines but not in term loans. We attempt to provide an explanation for this difference in Section 5, but first we address concerns about the endogeneity of the loan syndicate structure in the next section.

\subsection{Endogeneity concerns}

To the extent that the lead share and the syndicate structure change in expectation of future renegotiations, they would evolve endogeneously over time. To address this possibility, we start by investigating the evolution of syndicates over the life of the loan (Section 4.1.1). Next, we investigate the impact of the syndicate structure on renegotiations using a set of credit line renegotiations that are likely unexpected by the lead arranger, which makes it unlikely for the syndicate structure to change because of renegotiations (Section 4.1.2). An additional type of endogoneity, however, may be that lead share/syndicate diversity proxies are driven by a common unobserved factor that is correlated with the likelihood of renegotiation. To address this concern, we rely on instrumental variables estimation in Section 4.1.3 and on logit borrower fixed effects in Section 4.1.4.

\subsubsection{The evolution of loan syndicates}

A potential concern with the findings we reported thus far is that lead bank shares and syndicate diversity may be correlated with an unobserved factor that is in turn correlated with the likelihood of renegotiation. In the data, this can be manifested as a non-random sorting in the cross-section between renegotiations and lead bank share/syndicate diversity since the date the loan was originated. It is also possible that the lead bank share and syndicate diversity change 
in expectation of renegotiations, which would have time-series implications. In this section, we gauge whether these forms of endogeneity are manifested in our sample.

Figure 5 shows the developments of mean lead shares, non-bank types, and non-bank shares. In Figure 5a the mean lead share in credit lines is almost unchanged for the three-year period prior to the renegotiation. This pattern is also observed for non-bank shares (Figure $5 \mathrm{~b})$ and the number of non-bank types (Figure 5c). The mean lead bank share in term loans increases prior to the renegotiation year, but the increase is not statistically significant (Figure 5a, dashed line). The non-bank share in term loans exhibits a mild decrease, which also applies to the number of non-bank types. Overall, lead shares and syndicate diversity do not seem to change drastically before the renegotiation year. Rather, the renegotiation of term loans seems to trigger a significant change in lead bank shares, non-bank shares and non-bank types. These patterns indicate that lead bank shares and syndicate diversity are not evolving in a way that would justify the presence of anticipatory behavior by lead banks and syndicate participants.

To detect the presence of cross-sectional endogeneity that is potentially due to an omitted variable associated with unobserved credit quality correlated with lead shares/syndicate diversity and renegotiations, we analyze the differences in syndicate structures for renegotiated and non-renegotiated loans at origination (unreported). For credit lines, the differences between the mean lead bank shares for renegotiated and non-renegotiated loans are small and insignificant. A similar observation holds for other syndicate characteristics. For term loans, there are statistically significant differences, but they convey a mixed message with respect to the potential importance of endogeneity. For example, lead banks on average hold a smaller share in renegotiated than in non-renegotiated loans, but our previous analysis shows that the lead bank share helps predict renegotiations. In contrast, non-bank shares and the number of non-bank types are higher for renegotiated than for non-renegotiated loans in line with the results we unveil from our model on term loans renegotiations. To further reduce concerns with this form of endogeneity, in Section 4.1.3 we present results from instrumental variables and estimations of borrower fixed effects. 


\subsubsection{Expected and unexpected credit line renegotiations}

In this section, we focus on a subset of presumably unexpected credit line renegotiations, which should be less likely to trigger ex ante adjustments in the loan syndicate structure. To identify unexpected renegotiations, we impose two conditions on credit line renegotiations. First, the borrower must have a large portion of undrawn funds over the entire life of the loan before the renegotiation (we use $60 \%$ availability). ${ }^{14}$ Second, immediately after the renegotiation, borrowers' drawdowns are larger than the available amount prior to the renegotiation year. The first condition assures us that the borrower has plenty of available funding before the renegotiation, thus the request for an amount increase is less likely. The second condition guarantees that the borrower could not have met its immediate funding needs without increasing the credit line through a renegotiation.

Our conjecture is that these renegotiations are likely driven by an extra-large sudden funding need, which is hard to predict based on available observable information about the borrower. Based on pre-renegotiation firm controls, there does not seem to be a consistent pattern that would point to the arrival of renegotiation requests. For example, unexpected renegotiations are more prevalent for unrated borrowers with weaker growth opportunities, which have similar profitability and capital expenditures as for expected renegotiations. The mean lead share is slightly higher for unexpected renegotiations; however, the number of non-bank lenders and non-bank HHI is the same. Overall, our definition of an unexpected renegotiation is not correlated meaningfully with firm controls, which serves its purpose to isolate unexpected renegotiations. ${ }^{15}$

Table 3 reports estimates for expected and unexpected renegotiations of credit lines. ${ }^{16}$ The impact of the lead bank share on expected renegotiations is 2.211 (column 1) and 3.076 for unexpected ones (column 2). The magnitudes of the estimates of Non-bank lenders in columns

\footnotetext{
${ }^{14}$ We have used more conservative threshold levels at the $70 \%$ and $85 \%$ availability.

${ }^{15}$ To reduce concerns that the first renegotiation itself will produce information about the likelihood of subsequent renegotiations, we consider only the first renegotiation in the life of each credit line. We find that $12 \%$ of all credit line renegotiations are unexpected.

${ }^{16}$ The base category of expected does not contain unexpected renegotiations.
} 
(3) and (4) are similar for expected and unexpected renegotiations. As for Non-bank HHI in columns (5) and (6), the impact of expected renegotiations is stronger, while the opposite is true for the impact of Non-bank share in columns (7) and (8). ${ }^{17}$ Overall, our results show that the impacts of lead bank share and syndicate diversity are not very different for expected and unexpected credit line renegotiations, thus alleviating, at least in part, concerns about severe estimation biases.

\subsubsection{Instrumental variables estimation}

To the extent that we do not control for borrower- or bank-specific characteristics, which explain the relationship between renegotiations and syndicate structure, our coefficient estimates may be potentially biased. Unobserved credit and/or lender quality are two potential factors that may be linked to lead bank share and syndicate diversity. The higher likelihood of renegotiations in this case would not be driven by the lead bank share and/or syndicate diversity per se but by uncontrolled credit quality.

One way to address this concern is to use instruments that are correlated with lead share and syndicate diversity but do not affect the renegotiations directly, except through lead bank share and syndicate diversity. We use the concentration of the loan portfolio of the lead bank in a given year as an instrument for the lead share in a given loan. It is computed as the HHI index of the new loans the lead bank originates in a given year. ${ }^{18}$ Our instrument will likely reflect lead banks' overall policies about the concentration and risk exposure of the syndicated loan portfolio and is not driven by loan renegotiations per se. At the same time, more concentrated loan portfolios will likely be positively correlated with the lead bank share in a given loan.

The upper panel of Table 4 reports the second stage results for credit lines and term

\footnotetext{
${ }^{17}$ Table A2.1 in Appendix 2 reports the results from linear probability regressions, which are easier to compare across models of expected and unexpected renegotiations. The results yield similar conclusions to those based on the logit models.

${ }^{18}$ To compute that index, we sum up the total amount of all loans originated by lead banks each year and then calculate the sum of the squared ratio of loan amount to the total amount across all loans in the portfolio. For each loan, we exclude its own share from the index to ensure that our measure is not driven by mechanical correlation.
} 
loans, columns (1) and (5) respectively. The coefficients of the IV variable at the first stage for credit lines and term loans (unreported) are, respectively, 0.19 and 0.05 (significant at the 1\% level), indicating that this variable is a viable instrument. Since we use IV probit estimation, we estimate the corresponding probit regressions in the lower panel. Looking at the results, we see that if we do not use instrumental variables, the estimates of the lead bank share are lower for both credit lines and term loans.

We use a different set of instrumental variables for the syndicate diversity proxies. They capture the co-movements of retained shares across lender pairs for a given year. Positive correlations indicate that syndicate lenders tend to increase/decrease their shares together, while negative correlations indicate a lack of synchronized behaviour. The reason for this comovement can be similar business models, or an unobserved relationship between the lead bank and certain non-bank lenders, which makes the non-bank lenders alter their shares simultaneously. We use sets of pairs, such as CLOs and mutual funds, CLOs and finance companies, and mutual funds and finance companies, and so forth. The choice of lender pairs does not affect the quality of the instruments. More importantly, these co-movements are strongly related to syndicate diversity but they do not affect renegotiations per se. The intuition is that the driving force behind these instruments is preference and choice of lender investment decisions that are not bound by a borrower's renegotiation needs.

The upper panel of Table 4 reports the results for the IV probits for the syndicate diversity proxies. Columns (2) to (4) report the results for credit lines while columns (6) to (8) report the results for term loans. The corresponding probit results are reported in the lower panel. Overall, we find that the IV results are stronger than the probit results, suggesting that the results without instrumental variables establish a lower bound of the estimates from the probit model.

\subsubsection{Borrower fixed effects}

To further address the possibility that the lead share and our syndicate diversity proxies are correlated with unobservable credit quality that may drive likelihood of renegotiation, we estimate the same regression we estimated in our main specification using logit borrower fixed 
effects. The results of this exercise are reported in Table 5; columns (1) to (4), and (5) to (8) show results for credit lines and term loans, respectively. Comparing these results with the corresponding estimates in our initial analysis, reported in Table 2, they all take the same sign. Therefore, if borrower fixed effects account for unobserved credit quality, the coefficients of interest remain unchanged once we control for it.

\section{Which Non-bank Lenders Affect Renegotiations?}

In the previous section we documented that while the diversity of non-bank lenders hampers the prospects of renegotiation of credit lines, this is not the case for term loan renegotiations. The finding for term loans is contrary to our expectations because the diversity of non-bank investors is much higher in term loan than in credit line syndicates, and yet it plays a positive role in renegotiations. In this section, we attempt to explain this puzzling result. Higher diversity among non-bank lenders is likely a barrier to renegotiations, but if some non-bank lenders have incentives to support renegotiations because of their business models, the puzzling result can be explained. To investigate this hypothesis, we examine whether the presence and the shares of each non-bank lender type affects renegotiations.

Table 6, columns (1) to (3), report the results when we include indicator variables to account for the presence of each non-bank lender type in the syndicate. For example, if CLOs are present in the syndicate, the variable $C L O d$ takes the value one and zero otherwise. The positive estimate on $C L O d$ in column (1) suggests that the likelihood of a renegotiation is higher if a CLO is present in the syndicate. Holding all other variables at their means, if CLOs are present in the syndicate the odds of a renegotiation are $60 \%$. Interestingly, although funds (mutual funds, hedge funds and pension funds) have similar presence in term loans compared with CLOs, they do not appear to play as active role in renegotiations as CLOs do. The same conclusion applies to finance, broker and insurance companies.

In columns (2) and (3), we split the sample into two periods, before and after the year 2000, respectively because the presence of non-bank lenders has increased significantly in more recent years. Indeed, in column (2), CLOs do not matter for renegotiations in the pre-2000 
period, when they are present in only $7.8 \%$ of term loans, while they matter in the post-2000 period, when their participation rate went up to a $26.7 \%$. In the pre-2000 period, the estimate on $C L O d$ has a small magnitude and does not play any meaningful role in renegotiations. In contrast, in the post-2000 period, based on the estimate of $C L O d$ the renegotiation probability is $84 \%$ if CLOs are present in the syndicate. This time-series effect is important because it overlaps with the rise of CLOs in the syndicated loan market and in a way identifies the role of CLOs more precisely - upon their arrival, CLOs started playing an influential role in loan renegotiations.

Columns (4) to (6) report the results when we expand our models to include the loan shares of each non-bank lender type. ${ }^{19}$ In column (4), a change in the CLO share from the 25 th to the 75 th percentile increases the predicted renegotiation probability from $3 \%$ to $4 \%$. The positive significant effect of $C L O d$ is preserved, which suggests that higher CLO shares bring an additional increase to the likelihood of renegotiations. In column (5), the sample is restricted to the pre-2000 period. Given that CLOs were less present in the syndicated loan market in this period, neither their share nor their participation plays a role.

These findings indicate that the puzzling result we unveiled that more diversity among non-bank lenders is favorable to term loan renegotiations derives from the positive effect that CLOs have on renegotiations. This poses an interesting question: why do CLOs act so differently from the remaining non-bank investors and strongly support amount-increase renegotiations? We attempt to answer this question below.

\subsection{What drives CLOs' renegotiation decisions?}

CLOs are actively managed vehicles whereby the manager buys and sells individual bank loans for the underlying collateral pool during the entire lifetime of the CLO in an effort to create trading gains and minimize losses from deteriorating credits. ${ }^{20}$ In this context, it is not

\footnotetext{
${ }^{19}$ If non-bank types are absent from the syndicate, their shares take the value of zero. Because some nonbank lenders are present in a small subset of the loans, we include a set of dummy variables for the presence of non-bank lender types and the interaction terms with the corresponding non-bank shares.

${ }^{20}$ Some of the daily CLO manager obligations are to determine the credit risk of the assets, select various collateral quality test levels related to spread, recovery and other portfolio characteristics and assign the market value of certain assets. For their active collateral management, the CLO manager is compensated with three
} 
surprising that CLOs have incentives to support renegotiations that require additional funding because these will provide them with additional investment opportunities.

CLOs' incentives to support renegotiations will likely be enhanced if the CLO has a relationship with the lead bank of the loan under renegotiation. In particular, if the lead bank of the loan under renegotiation is the bank that has underwritten the CLO deal, this will likely give the CLO manager stronger incentive to approve the renegotiation. This relationship between CLOs and lead banks is likely valuable for the CLO because it can facilitate their access to investments for the current and the future CLO portfolio. It is also valuable for the lead bank because lead banks can expand their future underwriting business. CLO underwriters help structure the CLO deal and are responsible for distributing it. Additionally, they often provide a credit facility for the acquisition of corporate loans before the launch of the CLO and may even give the CLO the opportunity to invest in some of the loans they originate. ${ }^{21}$ In a nutshell, we expect CLOs to be more supportive of those renegotiations of loans that are arranged by the same lead bank that is also an underwriter of the CLO deal.

To investigate that hypothesis, we distinguish the share owned by related CLOs, Related CLO share, from the share owned by unrelated CLOs, Unrelated CLO share. Related CLO share is the summation of all CLO shares that have the lead bank as an underwriter, while the rest are defined as Unrelated CLO share. Figure 4 shows that the Related $C L O$ share has grown over time to the extent that is higher than the Unrelated $C L O$ share since $2000 .{ }^{22}$ Table 7 reports the results of this investigation. In column (1), we report logit regression estimates for the entire sample, and in columns (2) and (3), we split the sample into two periods: pre- and post-2000. In column (1), the estimate on Related CLO share is positive and significant, while the estimate on Unrelated $C L O$ share is not significant. A change from the 25 th to the 75 th percentile in the related CLO share distribution is associated with a change in the predicted

types of fees: senior (paid before the interest on senior tranches); junior (paid if the senior and mezzanine tranches receive their interest claims and collateral tests are met); and incentive (CLO equity returns exceed a prespecified threshold) fees. See Appendix 3 for more details.

\footnotetext{
${ }^{21}$ In Appendix 3 we illustrate the workings of a stylized CLO deal.

${ }^{22}$ Conditional on CLO presence, most of the loans have non-zero CLO related shares, which allows us to use the CLO dummy in the same way as in Table 6. Alternatively, we use a CLO related dummy that takes one if the facility has at least one related CLO and zero otherwise.
} 
probability of renegotiation from $3 \%$ to $4.3 \%$. Because CLOs have become prominent investors in loan syndicates since 2000, we expect the impact of Related CLO share on renegotiations to occur after 2000. In column (2), Related CLO share do not play a role in loan renegotiations in the pre-2000 period, while in column (3), where the post-2000 period is reported, they play a significant role. Interestingly, across all columns (1) to (3), the Unrelated CLO share does not play a role despite being as large as the Related CLO share.

Given that the largest CLO underwriters are also the largest leveraged-loan syndicators, such as J.P. Morgan, Citigroup, Credit Suisse, Goldman Sachs, a concern with the previous findings is that the relationship between the Related CLO share and loan renegotiations may be driven by unaccounted unobserved heterogeneity at the underwriter level. It could be that some underwriters prefer CLO managers with a stronger preference for active portfolio management and, hence, a stronger incentive to invest in leveraged loans. To control for unobserved heterogeneity, we estimate bank logit fixed effect regressions similar to those in Table 7. The results reported in Appendix 2, Table A2.2 still convey the fact that Related CLO share plays a prominent role in loan renegotiations, while this is not the case for the Unrelated CLO share.

To further understand the importance of the relationship between the CLO and the lead bank of the loan under renegotiation, we investigate whether the development of retained shares is consistent with coordinated interaction around the time of the renegotiation. To that end, we start by investigating CLO shares, in particular those of related CLOs, around the time of renegotiation. Figure 7 shows the total term loan growth for each lender type around the renegotiation year. The event window covers two years before (marked as -2 and -1 on the horizontal axis) and two years after (marked as 1 and 2 on the horizontal axis) the loan renegotiation. ${ }^{23}$ On the vertical axis is the ratio of the total loan amount for each lender, scaled by the total loan amount two years before a renegotiation (i.e., the growth rate is two years before the renegotiation). The dashed line shows the change in the loan amount for the entire loan (not split by a lender type). Owing to repayments, the total loan amount drops by $14 \%$ one

\footnotetext{
${ }^{23}$ Given that we use end-of-year data, the renegotiation occurs sometime between -1 and 0 . The event window covers the same number of years for each loan.
} 
year prior to the renegotiation, followed by a pronounced jump of 2.2 times in the renegotiation year compared to two years before the renegotiation. Consequently, lenders with loan growth higher than 2.2, which is the loan growth of the entire loan at the time of renegotiation compared with two years before the renegotiation increase, their relative contribution to the loan, while lenders with a lower loan growth decrease their relative participation in the loan.

As shown in Figure 7, the highest loan growth rate in the year of renegotiation is incurred by CLOs, at 2.9, followed by funds at 2.4. Importantly, this is driven by related CLOs that have as an underwriter the lead bank of the loan under renegotiation. These CLOs have the highest loan growth around the renegotiation, at 3.8 times. Interestingly, lead banks decrease their relative shares because they contribute only 1.57 times at the year of renegotiation, while the total loan increases by 2.2 times relative to two years before the renegotiation. In terms of other lenders, funds increase while finance companies decrease their relative shares. As for participant banks, they preserve their relative contribution in the renegotiated loan.

These findings suggest that related CLOs step in with higher contributions to make up for the decline in lead bank shares. Figure 8 shows the sum of lead bank shares and lender shares before and after the loan renegotiation (averaged at the loan level) that appears to be done predominantly by related CLOs. The reason is that the sum of lead bank shares and related CLO shares remains unchanged, although the former is declining and the latter is increasing. This finding corroborates the view that there is some coordination between related CLOs and lead banks around the time of the loan renegotiation in which related CLOs finance the portion of the loan increase that belonged to the lead bank. Since these additional investments are attractive for CLOs, this likely explains their ex ante support to amountincrease renegotiations.

It is possible that the patterns depicted in Figure 8 are not the result of any coordination between related CLOs and lead banks, but instead derive from other factors that coincide with the renegotiation event. To reduce concerns with this possibility, we estimate a set of regressions with lender shares as dependent variables, controlling for the same set of variables as in the main regression. The results of this investigation are reported in Table 8. Our 
coefficient of interest After renegotiation, takes the value of one for the period after the loan renegotiation and zero otherwise. From column (1), the lead share drops by 3.5 percentage points after the loan renegotiation. During the same time period, the CLO share increases by 2.1 percentage points (column 2). This increase is driven by related CLOs; their share goes up by 2.9 percentage points (column 3 ). None of the other non-bank investors increase their loan share following the renegotiation. The estimates for funds and finance company shares, reported respectively in columns (3) and (4), show a slight decrease in their shares while those for brokers and insurance companies show no change in their relative shares after the loan renegotiation (columns 5 to 7 ).

To sum up, we find that the puzzling result that higher non-bank diversity appears to be helpful to borrowers that wish to renegotiate their term loans derives from their coordination with the lead bank of the loan under renegotiation. In particular, this effect is driven by CLOs that have a relationship with the lead bank of the loan under renegotiation. The support of these CLOs to renegotiate appears to be driven by an incentive to increase their investments, possibly because by the time of the renegotiation the asymmetry of information vis-á-vis the borrower has significantly declined. Related CLOs not only fund the portion of the loan increase they are responsible for (by virtue of their loan share), but also the part of the loan increase that was supposed to be funded by the lead bank. Basically, this allows the lead bank to support the renegotiation without using additional funds, which could be used for the origination of new loans. As a result, while the Related CLO share increases, the lead bank shares decline at the time (or immediately after) of renegotiation. Interestingly, the sum of these two shares remains flat, adding support to our conjecture for the presence of some form of coordination between the lead bank and the related CLOs.

\section{Robustness}

In this section, we report several robustness tests related to time-series effects, logit fixed effect estimation, and the role of zero lead shares. 


\subsection{Is there a time effect?}

Non-bank lenders started increasing their presence in the syndicated term loan market after 2000. The term loan results in Table 2, columns (6) to (8), are expected to be more pronounced in the later period of our sample when the presence of CLOs has grown substantially, as shown in Figure 3. Exploring the time-series effect of non-bank lenders provides additional evidence of the role of an increased non-bank presence in the term loan market. To that end, we split our sample of term loans into two periods, before and after 2000. Based on the results in Table 9, the estimates on Lead bank share, \# Non-bank types, Non-bank HHI and Non-bank share are significant and take the expected signs for both periods. In terms of the relative importance of our coefficients of interest, a change from the 25 th to the 75 th percentile of the lead bank share changes the renegotiation probability pre-2000 from to $2.5 \%$ to $3 \%$, and from $2.8 \%$ to $4 \%$ post-2000. A similar pattern is observed for the pre-/post-2000 comparisons for \# Non-bank types, Non-bank HHI, and Non-bank share. These results confirm that in addition to the cross-sectional loan effects, there is a time-series effect as well. They also confirm that non-bank lenders' impact on term-loan renegotiations has increased over time, in line with their growing presence in loan syndicates.

\subsection{Does unobserved heterogeneity play a role?}

In this section, we report results from loan logit fixed effect estimation, which accounts for the role of unobserved factors at the loan level. It is possible that the lead bank share and the syndicate structure are correlated with an unobservable variable at the loan level whose inclusion could distort our main estimates and their interpretation. To alleviate this concern, in Table 10 we re-estimate Table 2 using a conditional loan logit fixed effect model. Such estimation is feasible because of the loan panel structure of the data. The results show that for both credit lines and term loans, the estimates of the coefficients of interest Lead Bank Share, \# Non-bank types, Non-bank HHI, and Non-bank share preserve their signs and significance. Overall, our results are not affected by the estimation method and continue to hold when the much more restrictive logit fixed effect method is used. 


\subsection{What about zero lead bank shares?}

The results presented in Section 2 show that a higher lead bank share increases the chances of renegotiation. This finding poses an interesting question: what happens in the extreme case when the lead bank divests itself entirely from the loans it originates? In general, lead banks keep a portion of the loan at the time of the loan origination, but in $8.3 \%$ of the loan-years, lead banks sell off their entire loan share in the years after loan the origination. With zero exposure to the loan, the lead bank will have little incentive to acquire information about the financial condition of borrowers. Additionally, the lead bank will have less bargaining power to convince the syndicate participants to increase their exposure to the borrower in the case of amount-increase renegotiations.

To assess the impact of the absence of an investment by the lead bank on the renegotiation prospects, we rerun the models reported in Table 2, with a dummy variable Zero Lead, which takes the value one if the lead bank has no investment in the loan. The results of this investigation are reported in Table 11. In columns (1) to (4), we report results for credit line renegotiations and in columns (5) to (8), term loan renegotiations. Our results show that the absence of an investment by the lead bank is indeed a barrier to loan renegotiations for both credit lines and term loans. This adds support to our previous findings that the lead bank retained share plays an important role by increasing borrowers' chances to renegotiate their loans successfully.

\section{Conclusion}

Over the last two decades, there was a rapid growth in the presence of non-bank investors in the corporate lending business. As a result, loan syndicates, which used to be dominated by banks, became increasingly heterogenous with a large number and diversity of non-bank lender lenders. Given that the initial loan terms can only be changed with a unanimous vote and that investor diversity may hamper it, one would expect the growing presence of non-bank investors in loan syndicates to reduce borrowers' ability to successfully renegotiate their loans. Indeed, we find strong supporting evidence for this hypothesis for credit line, but not for term 
loan renegotiations. In fact, in the case of term loans, non-bank investor diversity is helpful to renegotiations. This finding is puzzling in light of the existing theory. It is even more puzzling given that term loan syndicates are more diverse than credit line syndicates.

We find that our results on term loan renegotiations do not contradict theory because they derive from a complex form of coordination between two important players in term loan syndicates: the lead bank of the loan under renegotiation and CLOs, in particular those that have a relationship with that lead bank. CLOs' loan renegotiation support and their relationship with lead banks appear to be beneficial to both parties. It gives the lead bank the opportunity to support amount increase renegotiations without contributing additional funds, which is likely valuable for the lead bank since it will not have to commit more funding. This response by the lead bank does not deter the renegotiation because related CLOs take on the portion of the loan increase that was supposed to be funded by the lead bank (in addition to funding their own share of the loan increase). This too is likely valuable to CLOs because it gives them the opportunity to make additional investments in loans that they are already familiar with.

Our finding on the positive role of CLOs in amount-increase renegotiation contrasts the existing view on securitized vehicles in the literature. For example, Bord and Santos (2015) find that corporate loans that are securitized perform worse than similar loans originated by the same bank that are not securitized, while Demiroglu and James (2015)) document that CLOs act against debt restructuring of troubled loans. Our evidence on CLOs' supportive role in amount-increase renegotiations also highlights a novel channel through which these vehicles contribute to credit growth.

The interaction between CLOs and lead banks poses the question of whether this relationship is stable and whether a potential withdrawal of CLO funding would cause a meaningful supply shortage in the corporate loan market. Our paper leads to additional research questions, including whether the decline in retained shares by lead banks allows them to engage in new, supposedly more profitable lending business, whether related CLOs acquire new leveraged-loan pieces at a cheaper price, and whether CLOs monitor borrowers the same way as lead banks do. These questions are left for future research. 


\section{References}

Agarwal, S., Amromin, G., Ben-David, I., Chomsisengphet, S., and Evanoff, D. (2011). The role of securitization in mortgage renegotiation. Journal of Financial Economics, 102(3):559-578.

Arnold, M. and Westermann, R. (2016). The value of creditor governance: Debt renegotiations in and outside distress. Mimeo.

Benmelech, E., Dlugosz, J., and Ivashina, V. (2012). Securitization without adverse selection: The case of CLOs. Journal of Financial Economics, 106:91-113.

Berlin, M. and Mester, L. (1992). Debt covenants and renegotiation. Journal of Financial Intermediation, pages 95-133.

Bord, V. and Santos, J. (2012). The rise of the originate-to-distribute model and the role of banks in financial intermediation. FRBNY Economic Policy Review, July:21-34.

Bord, V. and Santos, J. (2015). Does securitization of corporate loans lead to riskier lending? Journal of Money, Credit and Banking, 47 (2-3):415-444.

Botlon, P. and Sharfstein, D. (1996). Optimal debt structure and the number of creditors. Journal of Political Economy, 104:1-25.

Demiroglu, C. and James, C. (2015). Bank loans and troubled debt restructuring. Journal of Financial Economics, 118:192-210.

Dessin, W. (2005). Information and control in ventures and alliances. Journal of Finance, 60:2513-2549.

Drucker, S. and Puri, M. (2005). On the benefits of concurrent lending and underwriting. Journal of Finance, 60 (6):2763-2799.

Garleanu, N. and Zwiebel, J. (2009). Design and renegotiation of debt contracts. Review of Financial Studies, 22:749-781. 
Gilson, S., Kose, J., and Lang, L. (1990). Troubled debt restructurings: An empirical analysis of private reorganization of firms in default. Journal of Financial Economics, 6:315-353.

Gorton, G. and Pennacchi, G. (1995). Banks and loan sales marketing nonmarketable assets. Journal of Monetary Economics, 35:389-411.

Hart, O. and Moore, L. (1988). Incomplete contracts and renegotiations. Econometrica: Journal of the Econometric Society, 50:755-785.

Holmström, B. and Tirole, J. (1997). Financial intermediation, loanable funds, and the real sector. Quarterly Journal of Economics, 112(3):663-691.

Ivashina, V. (2009). Asymmetric information effects on loan spreads. Journal of Financial Economics, 92:300-319.

Kashyap, A., Rajan, R., and Stein, J. (2002). Banks as liquidity providers: An explanation for the coexistence of lending and deposit-taking. Journal of Finance, 57:33-73.

Mian, A. and Santos, J. (2011). Liquidity risk and maturity management over the business cycle. Federal Reserve Bank of New York, mimeo.

Roberts, M. (2015). The role of dynamic renegotiation and asymmetric information in financial contracting. Journal of Financial Economics, 116:61-81.

Roberts, M. and Sufi, A. (2009). Renegotiation of financial contracts: Evidence from private credit agreements. Journal of Financial Economics, 93:159-184.

Sufi, A. (2007). Information asymmetry and financing arrangements: Evidence from syndicated loans. Journal of Finance, 62:629-668. 
Table 1: Sample Summary Statistics

This table presents loan, lead bank, non-bank lender and bank summary statistics. The period Pre-2000 covers the 1988-1999 period and Post-2000 covers the 2000-2010 period. All variables are defined in Appendix 1.

\begin{tabular}{|c|c|c|c|c|c|c|}
\hline & \multicolumn{2}{|c|}{ All Loans } & \multirow[t]{2}{*}{ Credit Lines } & \multicolumn{2}{|c|}{ Term Loans } & \multirow[b]{2}{*}{ Post-2000 } \\
\hline & & & & & Pre-2000 & \\
\hline & Mean & $\mathrm{SD}$ & Mean & Mean & Mean & Mean \\
\hline & \multicolumn{6}{|c|}{ Loan Characteristics } \\
\hline Lead bank share & 0.239 & 0.204 & 0.242 & 0.234 & 0.271 & 0.199 \\
\hline \# Non-bank types & 0.823 & 1.616 & 0.593 & 1.341 & 0.644 & 1.989 \\
\hline Non-bank HHI & 0.279 & 0.404 & 0.266 & 0.307 & 0.259 & 0.352 \\
\hline Non-bank share & 0.11 & 0.214 & 0.074 & 0.191 & 0.113 & 0.263 \\
\hline Participant bank shares & 0.552 & 0.259 & 0.628 & 0.452 & 0.524 & 0.456 \\
\hline Renegotiations & 0.073 & 0.26 & 0.092 & 0.031 & 0.025 & 0.036 \\
\hline Ln initial loan amount & 11.193 & 1.301 & 11.311 & 10.926 & 10.667 & 11.166 \\
\hline Loan rating & 85.979 & 34.644 & 88.707 & 79.823 & 80.483 & 79.209 \\
\hline CL draw-down ratio & 0.637 & 0.416 & 0.406 & 1.000 & 1.000 & 1.000 \\
\hline Maturity left & 3.812 & 2.37 & 3.542 & 4.419 & 4.766 & 4.097 \\
\hline Working capital & 0.372 & 0.483 & 0.469 & 0.151 & 0.110 & 0.19 \\
\hline $\mathrm{M} \& \mathrm{~A}$ & 0.131 & 0.338 & 0.096 & 0.212 & 0.219 & 0.205 \\
\hline Real estate & 0.093 & 0.290 & 0.039 & 0.214 & 0.223 & 0.206 \\
\hline Borrower rating & 0.150 & 0.357 & 0.183 & 0.076 & 0.057 & 0.094 \\
\hline \multirow[t]{2}{*}{ Credit line } & 0.693 & 0.461 & 1.000 & 0.000 & 0.000 & 0.000 \\
\hline & \multicolumn{6}{|c|}{ Non-bank Lender Characteristics } \\
\hline $\mathrm{CLO} \mathrm{d}$ & 0.081 & 0.272 & 0.038 & 0.176 & 0.078 & 0.267 \\
\hline Funds d & 0.109 & 0.312 & 0.069 & 0.199 & 0.106 & 0.285 \\
\hline Finance company d & 0.162 & 0.368 & 0.132 & 0.229 & 0.135 & 0.315 \\
\hline Broker company d & 0.072 & 0.259 & 0.061 & 0.098 & 0.053 & 0.140 \\
\hline Insurance company d & 0.054 & 0.226 & 0.024 & 0.122 & 0.054 & 0.185 \\
\hline Other lender d & 0.237 & 0.425 & 0.207 & 0.305 & 0.186 & 0.414 \\
\hline CLO share & 0.229 & 0.177 & 0.166 & 0.26 & 0.158 & 0.287 \\
\hline Related CLO share & 0.124 & 0.09 & 0.112 & 0.127 & 0.007 & 0.161 \\
\hline Unrelated CLO share & 0.142 & 0.136 & 0.108 & 0.159 & 0.150 & 0.161 \\
\hline Funds share & 0.171 & 0.147 & 0.129 & 0.204 & 0.273 & 0.18 \\
\hline Finance company share & 0.135 & 0.114 & 0.14 & 0.128 & 0.156 & 0.117 \\
\hline Broker company share & 0.074 & 0.086 & 0.078 & 0.069 & 0.116 & 0.052 \\
\hline Insurance company share & 0.07 & 0.101 & 0.073 & 0.069 & 0.132 & 0.051 \\
\hline \multirow[t]{2}{*}{ Other lender share } & 0.158 & 0.155 & 0.145 & 0.177 & 0.190 & 0.172 \\
\hline & \multicolumn{6}{|c|}{ Lead Bank Characteristics } \\
\hline Profitability bk & 0.003 & 0.002 & 0.003 & 0.002 & 0.002 & 0.003 \\
\hline Capital bk & 0.059 & 0.034 & 0.061 & 0.053 & 0.046 & 0.059 \\
\hline $\mathrm{L}$ assets bk & 18.327 & 1.906 & 18.464 & 18.014 & 17.241 & 18.696 \\
\hline Deposits bk & 0.368 & 0.25 & 0.383 & 0.334 & 0.334 & 0.334 \\
\hline Liquidity bk & 0.051 & 0.041 & 0.054 & 0.045 & 0.055 & 0.036 \\
\hline
\end{tabular}




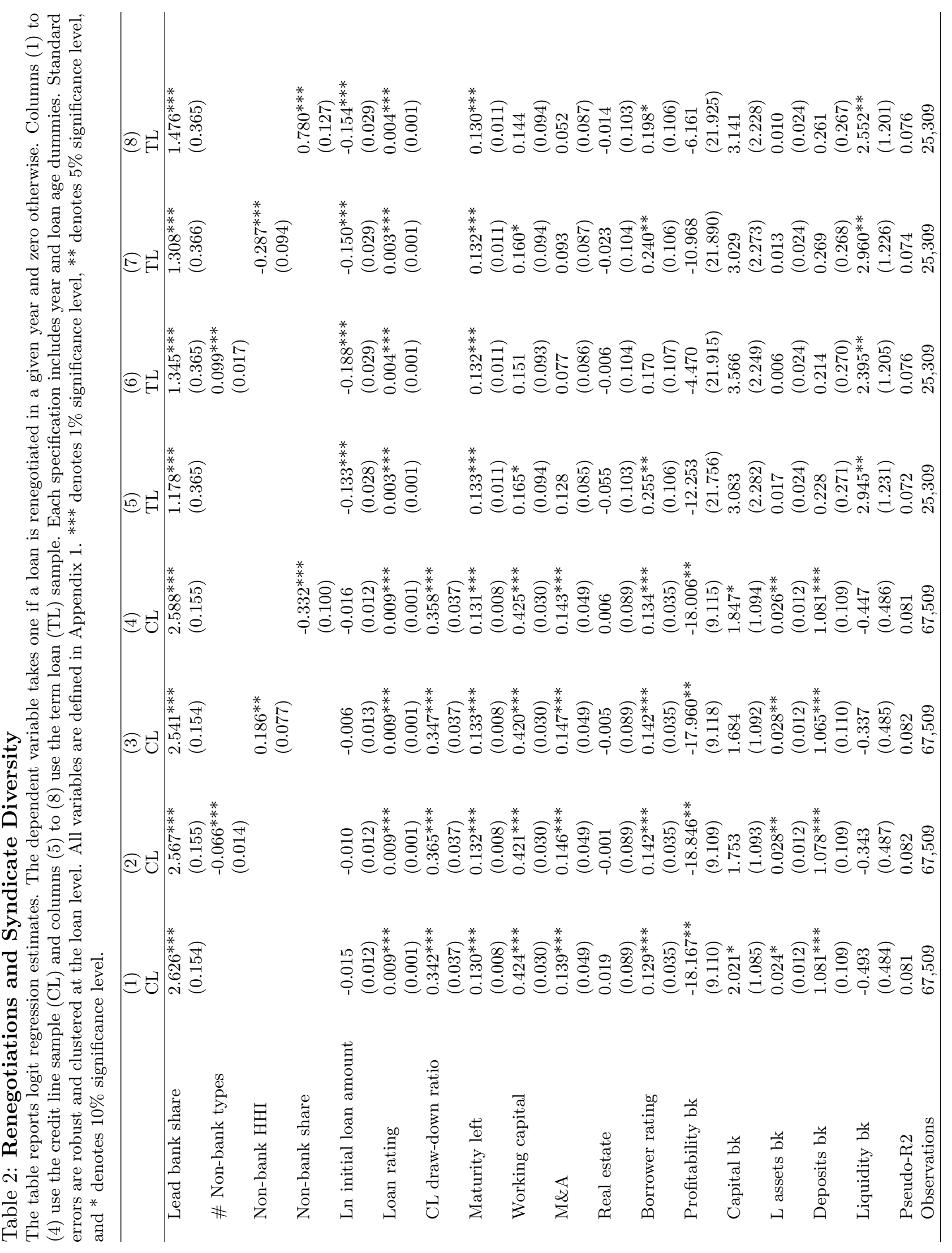




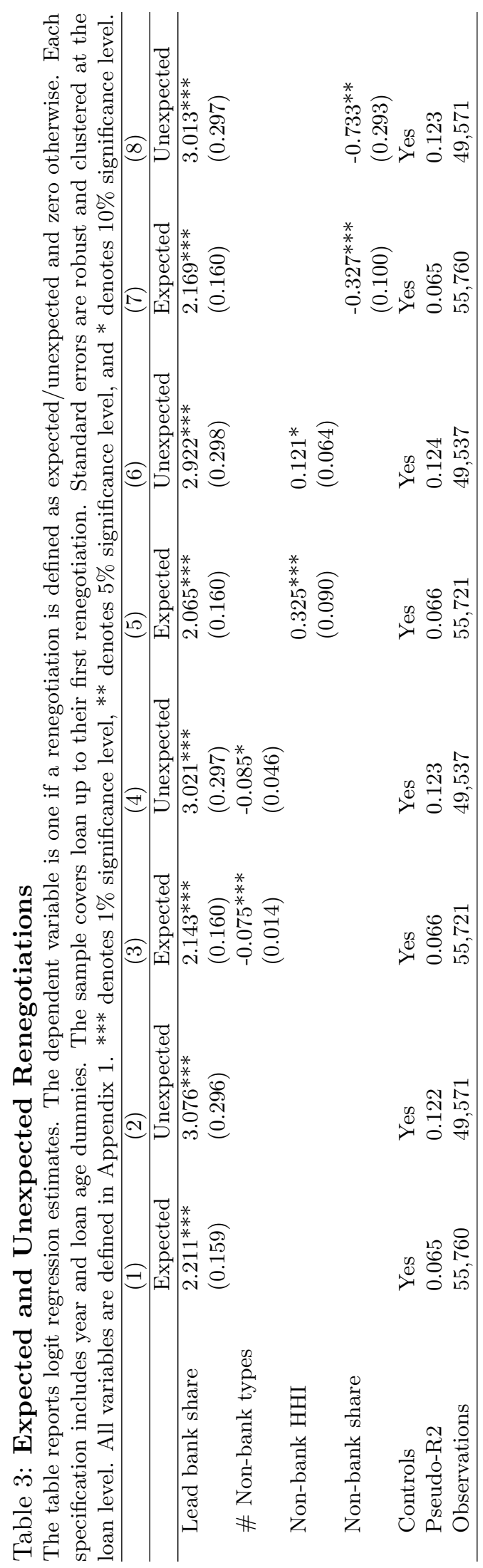




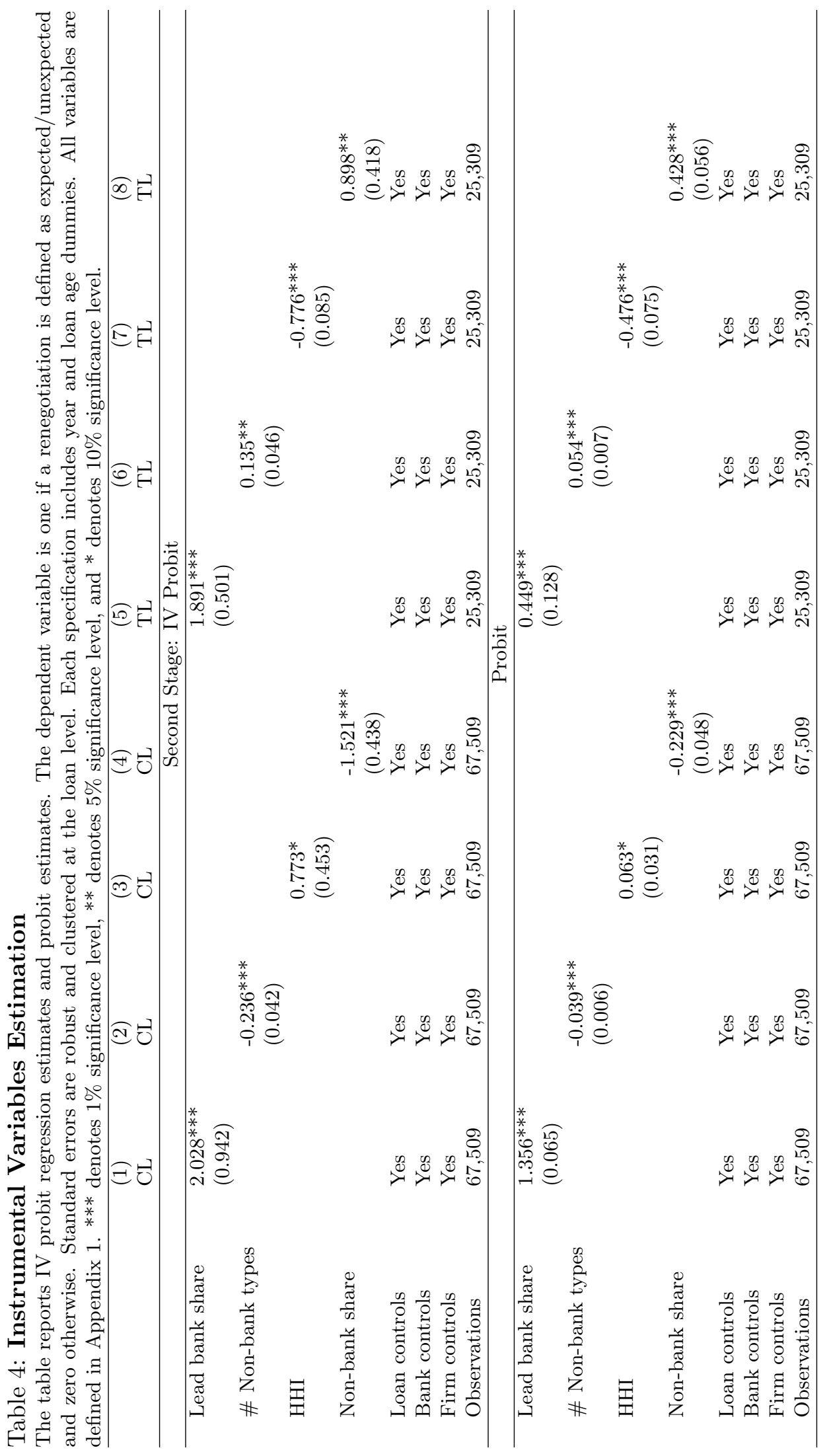




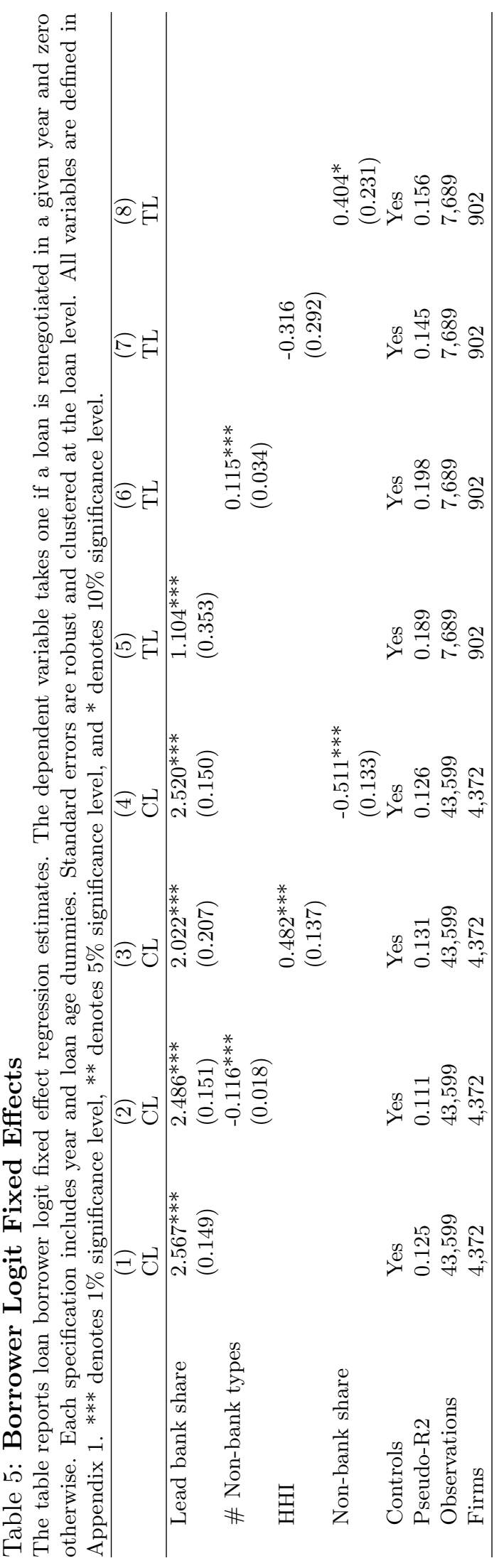


Table 6: Loan Renegotiations and Non-Bank Lenders in Term Loans

The table reports logit regression estimates. The dependent variable takes one if a loan is renegotiated and zero otherwise. Each specification includes year and loan age dummies. All variables are defined in Appendix 1 . *** denotes $1 \%$ significance level, $* *$ denotes $5 \%$ significance level, and * denotes $10 \%$ significance level.

\begin{tabular}{|c|c|c|c|c|c|c|}
\hline & (1) & (2) & (3) & (4) & (5) & $(6)$ \\
\hline & & Pre-2000 & Post-2000 & & Pre-2000 & Post-2000 \\
\hline \multirow[t]{2}{*}{ Lead bank share } & $1.380^{* * *}$ & $1.055^{* *}$ & $2.007 * * *$ & $1.464^{* * *}$ & $1.063^{* *}$ & $2.199^{* * *}$ \\
\hline & $(0.363)$ & $(0.469)$ & $(0.594)$ & $(0.364)$ & $(0.470)$ & $(0.594)$ \\
\hline \multirow[t]{2}{*}{ CLO d } & $0.455^{* * *}$ & 0.225 & $0.609 * * *$ & $0.259^{*}$ & -0.002 & $0.349^{*}$ \\
\hline & $(0.129)$ & $(0.225)$ & $(0.159)$ & $(0.154)$ & $(0.301)$ & $(0.185)$ \\
\hline \multirow[t]{2}{*}{ Funds d } & 0.042 & 0.150 & -0.086 & -0.034 & 0.074 & -0.131 \\
\hline & $(0.129)$ & $(0.232)$ & $(0.153)$ & $(0.159)$ & $(0.307)$ & $(0.185)$ \\
\hline \multirow[t]{2}{*}{ Finance company d } & 0.001 & 0.047 & 0.024 & -0.048 & 0.019 & -0.101 \\
\hline & $(0.099)$ & $(0.192)$ & $(0.117)$ & $(0.138)$ & $(0.273)$ & $(0.158)$ \\
\hline \multirow[t]{2}{*}{ Broker company d } & 0.084 & 0.193 & 0.052 & 0.061 & 0.179 & 0.089 \\
\hline & $(0.115)$ & $(0.245)$ & $(0.130)$ & $(0.143)$ & $(0.360)$ & $(0.163)$ \\
\hline \multirow[t]{2}{*}{ Insurance company d } & 0.015 & 0.128 & -0.063 & -0.102 & 0.325 & -0.249 \\
\hline & $(0.118)$ & $(0.236)$ & $(0.133)$ & $(0.149)$ & $(0.355)$ & $(0.164)$ \\
\hline \multirow[t]{2}{*}{ Other lender d } & $0.148^{*}$ & -0.122 & $0.262^{* *}$ & 0.089 & -0.036 & 0.180 \\
\hline & $(0.090)$ & $(0.162)$ & $(0.113)$ & $(0.115)$ & $(0.225)$ & $(0.137)$ \\
\hline \multirow[t]{2}{*}{ CLO share } & & & & $1.109^{* * *}$ & 1.370 & $1.498 * * *$ \\
\hline & & & & $(0.418)$ & $(1.283)$ & $(0.464)$ \\
\hline \multirow[t]{2}{*}{ Funds share } & & & & 0.347 & 0.240 & 0.144 \\
\hline & & & & $(0.421)$ & $(0.600)$ & $(0.616)$ \\
\hline \multirow[t]{2}{*}{ Finance company share } & & & & 0.447 & 0.155 & 1.003 \\
\hline & & & & $(0.580)$ & $(1.192)$ & $(0.636)$ \\
\hline \multirow[t]{2}{*}{ Broker company share } & & & & 0.445 & 0.037 & -0.396 \\
\hline & & & & $(1.104)$ & $(1.789)$ & $(1.796)$ \\
\hline \multirow[t]{2}{*}{ Insurance company share } & & & & 0.645 & -1.291 & 1.170 \\
\hline & & & & $(0.746)$ & $(1.579)$ & $(1.006)$ \\
\hline \multirow[t]{2}{*}{ Other lender share } & & & & 0.328 & -0.471 & 0.473 \\
\hline & & & & $(0.325)$ & $(0.797)$ & $(0.359)$ \\
\hline \multirow[t]{2}{*}{ Ln initial loan amount } & $-0.178^{* * *}$ & $-0.132^{* *}$ & $-0.192^{* * *}$ & $-0.165^{* * *}$ & $-0.128^{* *}$ & $-0.170^{* * *}$ \\
\hline & $(0.029)$ & $(0.051)$ & $(0.036)$ & $(0.030)$ & $(0.052)$ & $(0.037)$ \\
\hline \multirow[t]{2}{*}{ Loan rating } & $0.004^{* * *}$ & $0.004^{* *}$ & $0.003^{* * *}$ & $0.004^{* * *}$ & $0.004^{* * *}$ & $0.003^{* * *}$ \\
\hline & $(0.001)$ & $(0.001)$ & $(0.001)$ & $(0.001)$ & $(0.001)$ & $(0.001)$ \\
\hline \multirow[t]{2}{*}{ Maturity left } & $0.133^{* * *}$ & $0.108^{* * *}$ & $0.163^{* * *}$ & $0.132^{* * *}$ & $0.108^{* * *}$ & $0.162^{* * *}$ \\
\hline & $(0.011)$ & $(0.016)$ & $(0.017)$ & $(0.011)$ & $(0.016)$ & $(0.017)$ \\
\hline \multirow[t]{2}{*}{ Working capital } & 0.144 & $0.367^{* *}$ & 0.076 & 0.142 & $0.372^{* *}$ & 0.077 \\
\hline & $(0.093)$ & $(0.164)$ & $(0.112)$ & $(0.093)$ & $(0.164)$ & $(0.112)$ \\
\hline \multirow[t]{2}{*}{$\mathrm{M} \& \mathrm{~A}$} & 0.058 & 0.167 & -0.008 & 0.043 & 0.163 & -0.039 \\
\hline & $(0.086)$ & $(0.131)$ & $(0.115)$ & $(0.088)$ & $(0.132)$ & $(0.117)$ \\
\hline \multirow[t]{2}{*}{ Real estate } & 0.002 & -0.206 & 0.177 & 0.002 & -0.210 & 0.180 \\
\hline & $(0.104)$ & $(0.177)$ & $(0.137)$ & $(0.104)$ & $(0.177)$ & $(0.137)$ \\
\hline Borrower rating & 0.172 & 0.226 & 0.121 & $0.179^{*}$ & 0.224 & 0.119 \\
\hline & $(0.107)$ & $(0.201)$ & $(0.124)$ & $(0.108)$ & $(0.201)$ & $(0.125)$ \\
\hline Profitability bk & -6.153 & 16.439 & -16.710 & -5.155 & 16.845 & -16.811 \\
\hline & $(21.852)$ & $(43.113)$ & $(25.831)$ & $(21.955)$ & $(43.289)$ & $(25.904)$ \\
\hline Capital bk & 3.636 & -6.076 & $6.927^{* * *}$ & 3.655 & -6.115 & $6.785^{* * *}$ \\
\hline & $(2.227)$ & $(4.517)$ & $(2.544)$ & $(2.223)$ & $(4.528)$ & $(2.561)$ \\
\hline $\mathrm{L}$ assets bk & 0.005 & $0.140^{* * *}$ & -0.042 & 0.007 & $0.142^{* * *}$ & -0.039 \\
\hline & $(0.024)$ & $(0.047)$ & $(0.027)$ & $(0.024)$ & $(0.047)$ & $(0.027)$ \\
\hline Deposits bk & 0.234 & 0.655 & 0.173 & 0.237 & 0.661 & 0.203 \\
\hline & $(0.269)$ & $(0.446)$ & $(0.355)$ & $(0.269)$ & $(0.445)$ & $(0.356)$ \\
\hline Liquidity bk & $2.374^{* *}$ & $3.633^{* *}$ & 0.081 & $2.334^{*}$ & $3.654^{* *}$ & 0.018 \\
\hline & $(1.201)$ & $(1.725)$ & $(2.083)$ & $(1.196)$ & $(1.727)$ & $(2.072)$ \\
\hline Pseudo-R2 & 0.077 & 0.063 & 0.097 & 0.078 & 0.063 & 0.063 \\
\hline Observations & 25,356 & 10,711 & 14,506 & 25,356 & 10,711 & 14,506 \\
\hline
\end{tabular}


Table 7: Loan Renegotiations and CLO Relationships with the Lead Bank

The table reports logit regression estimates. The dependent variable takes one if a loan is renegotiated in a given year and zero otherwise. Funds Share is the sum of mutual, hedge and pension fund shares. Each specification includes year and loan age dummies. All variables are defined in Appendix 1. ${ }^{* * *}$ denotes $1 \%$ significance level, ** denotes $5 \%$ significance level, and * denotes $10 \%$ significance level.

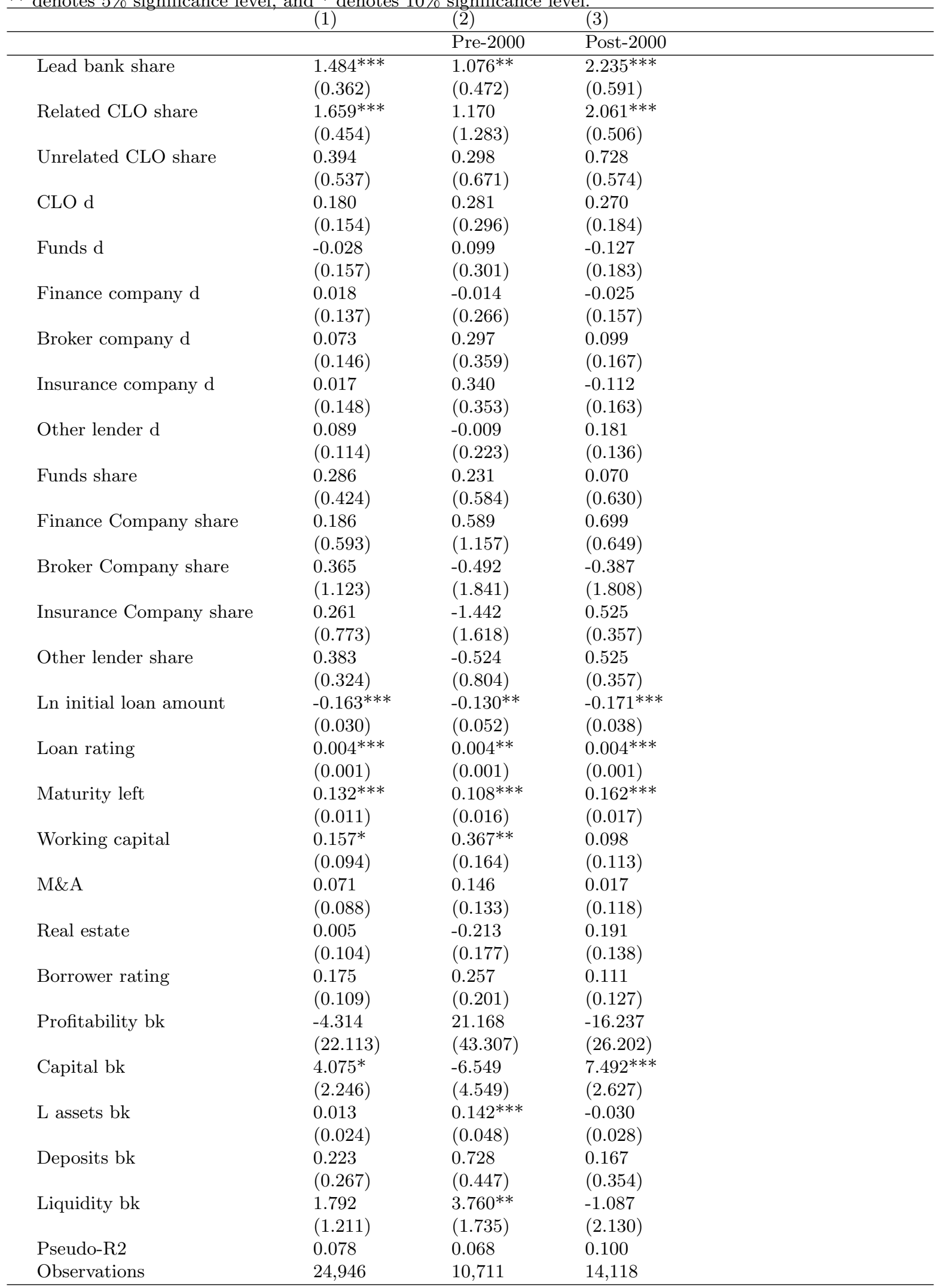


$\stackrel{\circ}{0}$

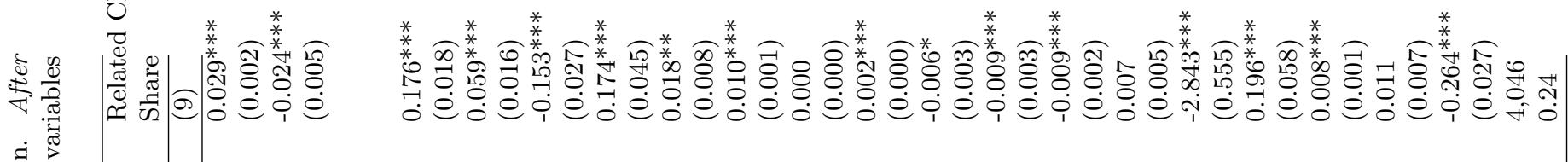

害弯

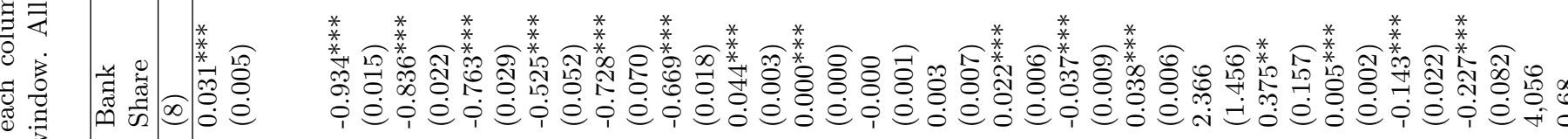
的

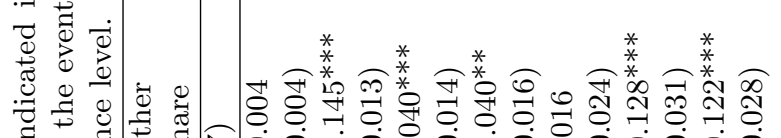

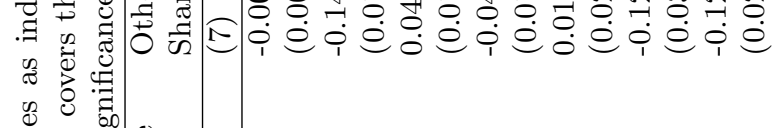

\& :

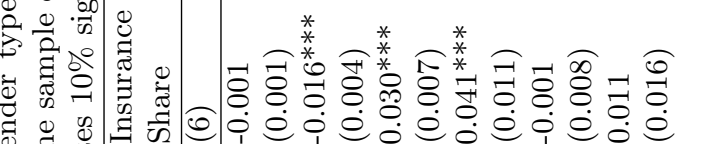

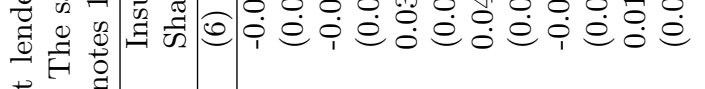

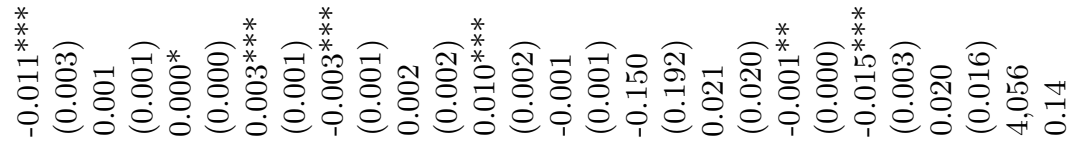
葛这部

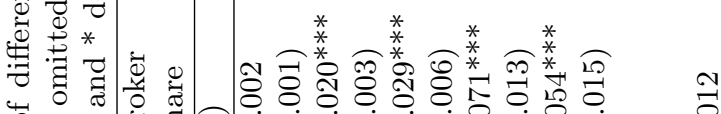

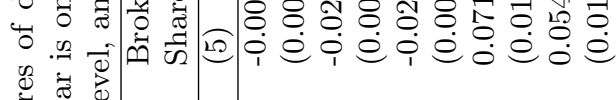

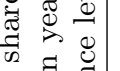

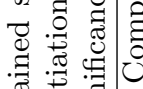

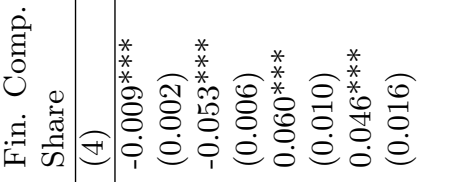

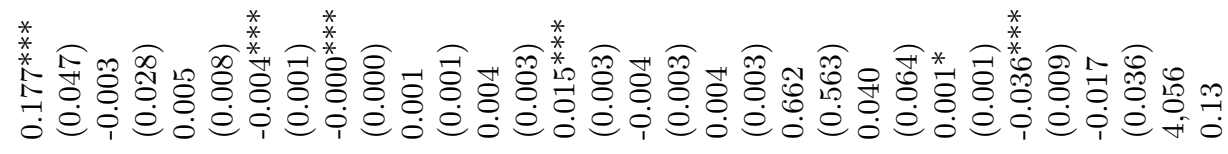
等

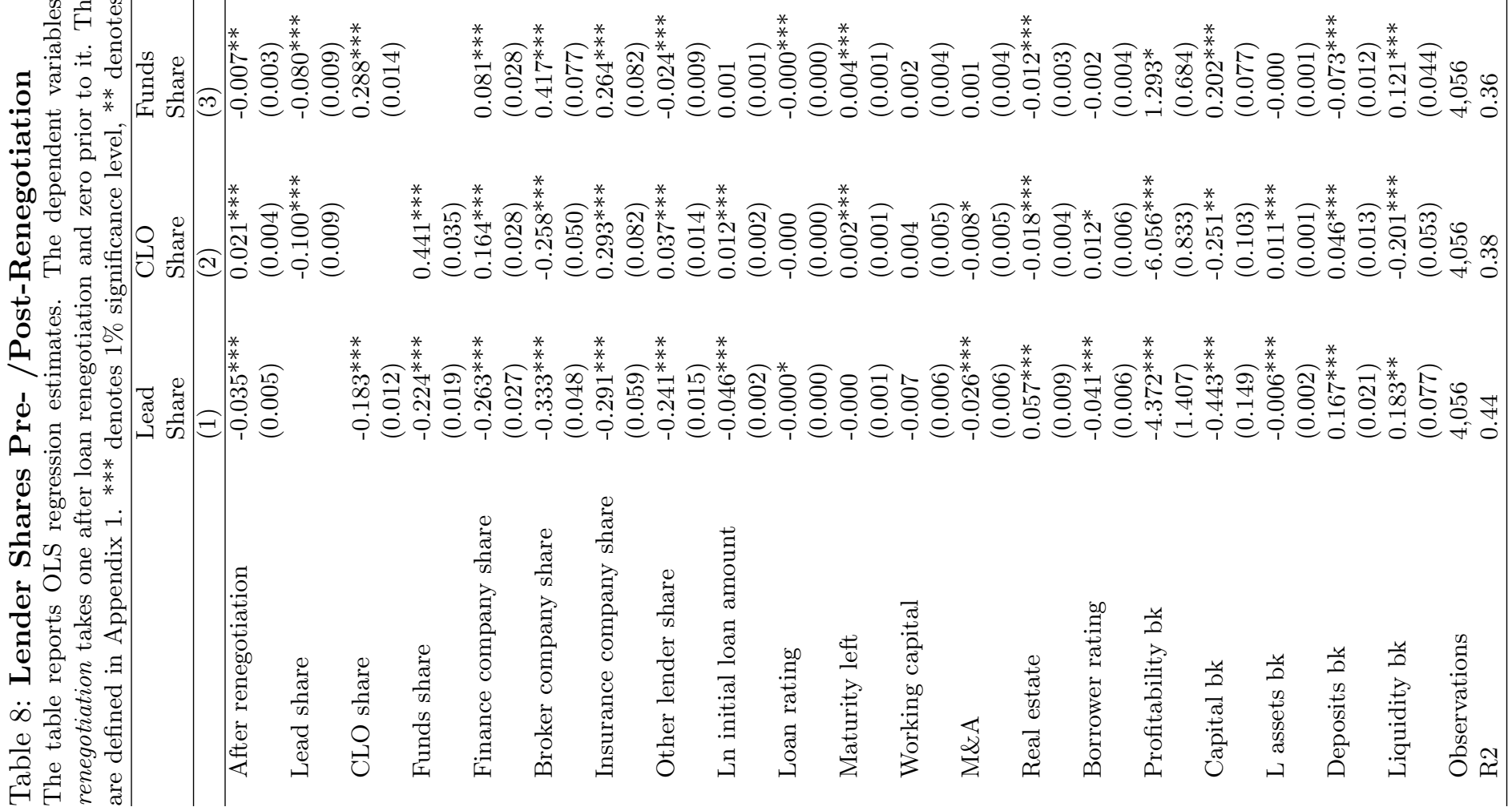


Table 9: Robustness: Loan Renegotiations of Term Loans Pre- and Post-2000

The table reports logit regression estimates. The dependent variable takes one if a loan is renegotiated in a given year and zero otherwise. Columns (1) to (4) cover the periods from 1988 to 2000 and columns (5) to (8) cover the period from 2001 to 2010. Standard errors are robust and clustered at the loan level. All variables are defined in Appendix 1. Each specification includes year and loan age dummies. *** denotes $1 \%$ significance level, $* *$ denotes $5 \%$ significance level, and $*$ denotes $10 \%$ significance level.

\begin{tabular}{|c|c|c|c|c|c|c|c|c|}
\hline & $(1)$ & $(2)$ & $(3)$ & $(4)$ & (5) & $(6)$ & (7) & $(8)$ \\
\hline & \multicolumn{4}{|l|}{ Pre-2000 } & \multicolumn{4}{|l|}{ Post-2000 } \\
\hline \multirow[t]{2}{*}{ Lead bank share } & $0.988^{* *}$ & $1.065^{* *}$ & $1.082^{* *}$ & $1.073^{* *}$ & $1.617^{* * *}$ & $1.930^{* * *}$ & $1.932^{* * *}$ & $2.182^{* * *}$ \\
\hline & $(0.466)$ & $(0.467)$ & $(0.468)$ & $(0.465)$ & $(0.605)$ & $(0.601)$ & $(0.604)$ & $(0.598)$ \\
\hline \multirow[t]{2}{*}{ \# Non-bank types } & & $0.087^{* *}$ & & & & $0.105^{* * *}$ & & \\
\hline & & $(0.039)$ & & & & $(0.021)$ & & \\
\hline \multirow[t]{2}{*}{ Non-bank HHI } & & & $-0.522^{*}$ & & & & $-0.882^{* * *}$ & \\
\hline & & & $(0.303)$ & & & & $(0.195)$ & \\
\hline \multirow[t]{2}{*}{ Non-bank share } & & & & $0.393^{*}$ & & & & $0.980 * * *$ \\
\hline & & & & $(0.218)$ & & & & $(0.166)$ \\
\hline \multirow[t]{2}{*}{ Ln initial loan amount } & $-0.116^{* *}$ & $-0.134^{* * *}$ & $-0.134^{* * *}$ & $-0.117^{* *}$ & $-0.142^{* * *}$ & $-0.210^{* * *}$ & $-0.194 * * *$ & $-0.170^{* * *}$ \\
\hline & $(0.050)$ & $(0.051)$ & $(0.051)$ & $(0.051)$ & $(0.035)$ & $(0.036)$ & $(0.035)$ & $(0.035)$ \\
\hline \multirow[t]{2}{*}{ Loan rating } & $0.003^{* *}$ & $0.004^{* * *}$ & $0.004^{* * *}$ & $0.004^{* * *}$ & $0.003^{* *}$ & $0.003^{* * *}$ & $0.003^{* * *}$ & $0.003^{* * *}$ \\
\hline & $(0.001)$ & $(0.001)$ & $(0.001)$ & $(0.001)$ & $(0.001)$ & $(0.001)$ & $(0.001)$ & $(0.001)$ \\
\hline \multirow[t]{2}{*}{ Maturity left } & $0.109^{* * *}$ & $0.107^{* * *}$ & $0.107 * * *$ & $0.107 * * *$ & $0.160^{* * *}$ & $0.160 * * *$ & $0.159 * * *$ & $0.158^{* * *}$ \\
\hline & $(0.016)$ & $(0.016)$ & $(0.016)$ & $(0.016)$ & $(0.017)$ & $(0.017)$ & $(0.017)$ & $(0.017)$ \\
\hline \multirow[t]{2}{*}{ Working capital } & $0.373^{* *}$ & $0.371^{* *}$ & $0.370^{* *}$ & $0.366^{* *}$ & 0.105 & 0.088 & 0.087 & 0.077 \\
\hline & $(0.164)$ & $(0.164)$ & $(0.164)$ & $(0.165)$ & $(0.113)$ & $(0.113)$ & $(0.112)$ & $(0.112)$ \\
\hline \multirow[t]{2}{*}{$\mathrm{M} \& \mathrm{~A}$} & 0.205 & 0.181 & 0.175 & 0.180 & 0.090 & 0.021 & 0.018 & -0.021 \\
\hline & $(0.130)$ & $(0.131)$ & $(0.131)$ & $(0.131)$ & $(0.112)$ & $(0.114)$ & $(0.114)$ & $(0.116)$ \\
\hline \multirow[t]{2}{*}{ Real estate } & -0.207 & -0.200 & -0.199 & -0.204 & 0.102 & 0.149 & 0.168 & 0.154 \\
\hline & $(0.176)$ & $(0.177)$ & $(0.177)$ & $(0.176)$ & $(0.134)$ & $(0.136)$ & $(0.137)$ & $(0.136)$ \\
\hline \multirow[t]{2}{*}{ Borrower rating } & 0.251 & 0.224 & 0.225 & 0.248 & $0.214^{*}$ & 0.112 & 0.141 & 0.126 \\
\hline & $(0.199)$ & $(0.201)$ & $(0.202)$ & $(0.200)$ & $(0.124)$ & $(0.125)$ & $(0.123)$ & $(0.123)$ \\
\hline \multirow[t]{2}{*}{ Profitability bk } & 11.464 & 13.784 & 13.713 & 14.930 & -22.221 & -12.739 & -15.908 & -17.024 \\
\hline & $(42.433)$ & $(42.468)$ & $(42.480)$ & $(42.491)$ & $(25.641)$ & $(25.842)$ & $(25.827)$ & $(25.922)$ \\
\hline \multirow[t]{2}{*}{ Capital bk } & -5.851 & -6.003 & -5.926 & -6.188 & $6.811^{* * *}$ & $7.024 * * *$ & $7.274 * * *$ & $6.613^{* * *}$ \\
\hline & $(4.508)$ & $(4.503)$ & $(4.510)$ & $(4.498)$ & $(2.550)$ & $(2.537)$ & $(2.546)$ & $(2.533)$ \\
\hline \multirow[t]{2}{*}{$\mathrm{L}$ assets bk } & $0.149^{* * *}$ & $0.142^{* * *}$ & $0.141^{* * *}$ & $0.145^{* * *}$ & -0.034 & $-0.045^{*}$ & $-0.046^{*}$ & -0.037 \\
\hline & $(0.046)$ & $(0.047)$ & $(0.047)$ & $(0.047)$ & $(0.027)$ & $(0.027)$ & $(0.027)$ & $(0.027)$ \\
\hline \multirow[t]{2}{*}{ Deposits bk } & 0.608 & 0.655 & 0.658 & 0.659 & 0.161 & 0.142 & 0.148 & 0.189 \\
\hline & $(0.443)$ & $(0.444)$ & $(0.445)$ & $(0.443)$ & $(0.350)$ & $(0.355)$ & $(0.354)$ & $(0.353)$ \\
\hline \multirow[t]{2}{*}{ Liquidity bk } & $3.723^{* *}$ & $3.672^{* *}$ & $3.653^{* *}$ & $3.727^{* *}$ & 0.979 & 0.218 & 0.305 & 0.178 \\
\hline & $(1.719)$ & $(1.716)$ & $(1.732)$ & $(1.721)$ & $(2.103)$ & $(2.073)$ & $(2.083)$ & $(2.055)$ \\
\hline Pseudo-R2 & 0.060 & 0.061 & 0.062 & 0.061 & 0.089 & 0.095 & 0.095 & 0.097 \\
\hline Observations & 10,711 & 10,711 & 10,711 & 10,711 & 14,506 & 14,506 & 14,506 & 14,506 \\
\hline
\end{tabular}




\section{Table 10: Robustness: Loan Logit Fixed Effects}

The table reports loan logit fixed effect regression estimates. The dependent variable takes one if a loan is renegotiated in a given year and zero otherwise. Standard errors are robust and clustered at the loan level. Each specification includes year and loan age dummies. All variables are defined in Appendix 1. *** denotes $1 \%$ significance level, $* *$ denotes $5 \%$ significance level, and $*$ denotes $10 \%$ significance level.

\begin{tabular}{|c|c|c|c|c|c|c|c|c|}
\hline & (1) & $(2)$ & (3) & (4) & (5) & (6) & (7) & (8) \\
\hline & CL & CL & $\mathrm{CL}$ & CL & TL & TL & TL & TL \\
\hline \multirow[t]{2}{*}{ Lead bank share } & $2.912^{* * *}$ & $2.780 * * *$ & $2.803^{* * *}$ & $2.851^{* * *}$ & $0.762^{*}$ & 0.498 & $0.800^{*}$ & $0.858^{*}$ \\
\hline & $(0.189)$ & $(0.189)$ & $(0.189)$ & $(0.190)$ & $(0.429)$ & $(0.447)$ & $(0.431)$ & $(0.455)$ \\
\hline \multirow[t]{2}{*}{ \# Non-bank types } & & $-0.154^{* * *}$ & & & & $0.105^{* *}$ & & \\
\hline & & $(0.024)$ & & & & $(0.045)$ & & \\
\hline \multirow[t]{2}{*}{ Non-bank HHI } & & & $0.337^{* * *}$ & & & & $-0.268^{*}$ & \\
\hline & & & $(0.123)$ & & & & $(0.141)$ & \\
\hline \multirow[t]{2}{*}{ Non-bank share } & & & & $-0.514^{* * *}$ & & & & $0.188^{*}$ \\
\hline & & & & $(0.184)$ & & & & $(0.098)$ \\
\hline \multirow[t]{2}{*}{ Loan rating } & $0.007^{* * *}$ & $0.007^{* * *}$ & $0.007^{* * *}$ & $0.007^{* * *}$ & 0.002 & 0.002 & 0.002 & 0.002 \\
\hline & $(0.001)$ & $(0.001)$ & $(0.001)$ & $(0.001)$ & $(0.002)$ & $(0.002)$ & $(0.002)$ & $(0.002)$ \\
\hline \multirow[t]{2}{*}{ CL drawdown ratio } & $0.226^{* * *}$ & $0.291^{* * *}$ & $0.238 * * *$ & $0.250^{* * *}$ & & & & \\
\hline & $(0.062)$ & $(0.063)$ & $(0.062)$ & $(0.063)$ & & & & \\
\hline \multirow[t]{2}{*}{ Maturity left } & $0.662^{* * *}$ & $0.666^{* * *}$ & $0.663^{* * *}$ & $0.664^{* * *}$ & $0.871^{* * *}$ & $0.865^{* * *}$ & $0.873^{* * *}$ & $0.872^{* * *}$ \\
\hline & $(0.016)$ & $(0.016)$ & $(0.016)$ & $(0.016)$ & $(0.048)$ & $(0.048)$ & $(0.048)$ & $(0.048)$ \\
\hline \multirow[t]{2}{*}{ Borrower rating } & 0.058 & 0.076 & 0.069 & 0.062 & $0.642^{*}$ & 0.585 & $0.646^{*}$ & $0.649^{*}$ \\
\hline & $(0.090)$ & $(0.091)$ & $(0.091)$ & $(0.091)$ & $(0.372)$ & $(0.371)$ & $(0.372)$ & $(0.372)$ \\
\hline \multirow[t]{2}{*}{ Profitability bk } & -18.244 & -20.565 & -17.911 & -18.458 & -1.380 & -5.845 & -0.791 & -0.568 \\
\hline & $(14.006)$ & $(14.024)$ & $(14.030)$ & $(14.010)$ & $(34.431)$ & $(34.523)$ & $(34.391)$ & $(34.430)$ \\
\hline \multirow[t]{2}{*}{ Capital bk } & 1.937 & 1.720 & 1.781 & 1.837 & -1.022 & -1.221 & -1.109 & -1.313 \\
\hline & $(2.282)$ & $(2.289)$ & $(2.286)$ & $(2.283)$ & $(6.097)$ & $(6.115)$ & $(6.098)$ & $(6.073)$ \\
\hline \multirow[t]{2}{*}{$\mathrm{L}$ assets bk } & 0.045 & 0.043 & 0.043 & 0.044 & $0.274^{*}$ & $0.292^{* *}$ & $0.268^{*}$ & $0.276^{*}$ \\
\hline & $(0.049)$ & $(0.049)$ & $(0.049)$ & $(0.049)$ & $(0.144)$ & $(0.144)$ & $(0.144)$ & $(0.143)$ \\
\hline \multirow[t]{2}{*}{ Deposits bk } & 0.409 & 0.386 & 0.371 & 0.399 & -1.550 & -1.682 & -1.498 & -1.519 \\
\hline & $(0.346)$ & $(0.347)$ & $(0.347)$ & $(0.346)$ & $(1.211)$ & $(1.218)$ & $(1.212)$ & $(1.212)$ \\
\hline \multirow[t]{2}{*}{ Liquidity bk } & $-2.108^{* *}$ & $-1.982^{*}$ & $-1.924^{*}$ & $-2.122^{* *}$ & -1.756 & -1.990 & -1.752 & -1.630 \\
\hline & $(1.010)$ & $(1.013)$ & $(1.013)$ & $(1.010)$ & $(3.244)$ & $(3.251)$ & $(3.245)$ & $(3.227)$ \\
\hline Pseudo-R2 & 0.189 & 0.191 & 0.191 & 0.189 & 0.231 & 0.233 & 0.231 & 0.231 \\
\hline Observations & 28,466 & 28,466 & 28,466 & 28,466 & 3,531 & 3,530 & 3,530 & 3,531 \\
\hline
\end{tabular}


Table 11: Robustness: Zero Lead

The table reports logit regression estimates. The dependent variable takes one if a loan is renegotiated in a given year and zero otherwise. Zero Lead Bank Share is a dummy variable that takes one if the retained share of the lead bank is zero. Standard errors are robust and clustered at the loan level. Each specification includes year and loan age dummies. All variables are defined in Appendix 1. *** denotes $1 \%$ significance level, ** denotes $5 \%$ significance level, and * denotes $10 \%$ significance level.

\begin{tabular}{|c|c|c|c|c|c|c|c|c|}
\hline & (1) & $(2)$ & $(3)$ & $(4)$ & $(5)$ & $(6)$ & (7) & $(8)$ \\
\hline & $\mathrm{CL}$ & $\mathrm{CL}$ & $\mathrm{CL}$ & $\mathrm{CL}$ & TL & TL & TL & $\overline{\mathrm{TL}}$ \\
\hline \multirow[t]{2}{*}{ Zero lead bank share } & $-0.145^{* * *}$ & $-0.127 * * *$ & $-0.144^{* * *}$ & $-0.124^{* * *}$ & $-0.255^{* * *}$ & $-0.134^{*}$ & $-0.177^{* *}$ & $0.113^{*}$ \\
\hline & $(0.048)$ & $(0.048)$ & $(0.048)$ & $(0.048)$ & $(0.098)$ & $(0.062)$ & $(0.087)$ & $(0.056)$ \\
\hline \multirow[t]{2}{*}{ \# Non-banks types } & & $-0.087^{* * *}$ & & & & $0.120^{* * *}$ & & \\
\hline & & $(0.014)$ & & & & $(0.018)$ & & \\
\hline \multirow[t]{2}{*}{ HHI } & & & $0.260^{* * *}$ & & & & $-1.127^{* * *}$ & \\
\hline & & & $(0.095)$ & & & & $(0.164)$ & \\
\hline \multirow[t]{2}{*}{ Non-bank share } & & & & $-0.482^{* * *}$ & & & & $0.907^{* * *}$ \\
\hline & & & & $(0.101)$ & & & & $(0.127)$ \\
\hline \multirow[t]{2}{*}{ Ln initial loan amount } & $-0.059^{* * *}$ & $-0.051^{* * *}$ & $-0.049^{* * *}$ & $-0.060^{* * *}$ & $-0.116^{* * *}$ & $-0.195^{* * *}$ & $-0.156^{* * *}$ & $-0.154^{* * *}$ \\
\hline & $(0.012)$ & $(0.012)$ & $(0.012)$ & $(0.012)$ & $(0.028)$ & $(0.028)$ & $(0.034)$ & $(0.028)$ \\
\hline \multirow[t]{2}{*}{ Loan rating } & $0.009^{* * *}$ & $0.009^{* * *}$ & $0.009 * * *$ & $0.009 * * *$ & $0.005^{* * *}$ & $0.005^{* * *}$ & $0.006^{* * *}$ & $0.005^{* * *}$ \\
\hline & $(0.001)$ & $(0.001)$ & $(0.001)$ & $(0.001)$ & $(0.001)$ & $(0.001)$ & $(0.001)$ & $(0.001)$ \\
\hline \multirow[t]{2}{*}{ CL drawdown ratio } & $0.343^{* * *}$ & $0.374^{* * *}$ & $0.361^{* * *}$ & $0.366^{* * *}$ & & & & \\
\hline & $(0.036)$ & $(0.037)$ & $(0.037)$ & $(0.037)$ & & & & \\
\hline \multirow[t]{2}{*}{ Maturity left } & $0.129^{* * *}$ & $0.133^{* * *}$ & $0.133^{* * *}$ & $0.131^{* * *}$ & $0.131^{* * *}$ & $0.132^{* * *}$ & $0.131^{* * *}$ & $0.130 * * *$ \\
\hline & $(0.008)$ & $(0.008)$ & $(0.008)$ & $(0.008)$ & $(0.010)$ & $(0.010)$ & $(0.012)$ & $(0.010)$ \\
\hline \multirow[t]{2}{*}{ Working capital } & $0.434^{* * *}$ & $0.429^{* * *}$ & $0.430 * * *$ & $0.433^{* * *}$ & $0.169^{*}$ & 0.146 & 0.138 & 0.141 \\
\hline & $(0.030)$ & $(0.030)$ & $(0.030)$ & $(0.030)$ & $(0.094)$ & $(0.093)$ & $(0.105)$ & $(0.093)$ \\
\hline \multirow[t]{2}{*}{$\mathrm{M} \& \mathrm{~A}$} & $0.145^{* * *}$ & $0.153^{* * *}$ & $0.157^{* * *}$ & $0.150^{* * *}$ & 0.097 & 0.041 & -0.018 & 0.021 \\
\hline & $(0.048)$ & $(0.048)$ & $(0.048)$ & $(0.048)$ & $(0.085)$ & $(0.086)$ & $(0.097)$ & $(0.087)$ \\
\hline \multirow[t]{2}{*}{ Real estate } & 0.051 & 0.023 & 0.014 & 0.031 & -0.107 & -0.049 & -0.068 & -0.060 \\
\hline & $(0.089)$ & $(0.089)$ & $(0.089)$ & $(0.089)$ & $(0.101)$ & $(0.101)$ & $(0.126)$ & $(0.102)$ \\
\hline \multirow[t]{2}{*}{ Borrower rating } & $0.100^{* * *}$ & $0.118^{* * *}$ & $0.118^{* * *}$ & $0.108 * * *$ & $0.282^{* * *}$ & $0.181^{*}$ & 0.077 & $0.224^{* *}$ \\
\hline & $(0.035)$ & $(0.035)$ & $(0.035)$ & $(0.035)$ & $(0.108)$ & $(0.108)$ & $(0.123)$ & $(0.107)$ \\
\hline \multirow[t]{2}{*}{ Profitability bk } & $-17.332^{*}$ & $-18.364^{* *}$ & $-17.379^{*}$ & $-17.256^{*}$ & $-76.434^{* * *}$ & $-87.721^{* * *}$ & $-88.147^{* * *}$ & $-85.500 * * *$ \\
\hline & $(9.119)$ & $(9.116)$ & $(9.117)$ & $(9.122)$ & $(17.116)$ & $(17.413)$ & $(20.003)$ & $(17.479)$ \\
\hline \multirow[t]{2}{*}{ Capital bk } & $1.780^{*}$ & 1.436 & 1.349 & 1.539 & 1.219 & 1.042 & 2.015 & 0.776 \\
\hline & $(1.082)$ & $(1.093)$ & $(1.094)$ & (1.093) & $(2.137)$ & $(2.092)$ & $(2.258)$ & $(2.063)$ \\
\hline \multirow[t]{2}{*}{$\mathrm{L}$ assets bk } & 0.016 & $0.021^{*}$ & $0.022^{*}$ & 0.019 & $0.065^{* * *}$ & 0.036 & 0.019 & $0.046^{* *}$ \\
\hline & $(0.012)$ & $(0.012)$ & $(0.012)$ & $(0.012)$ & $(0.024)$ & $(0.023)$ & $(0.028)$ & $(0.023)$ \\
\hline \multirow[t]{2}{*}{ Deposits bk } & $1.194^{* * *}$ & $1.188^{* * *}$ & $1.180^{* * *}$ & $1.193^{* * *}$ & 0.113 & 0.120 & -0.050 & 0.173 \\
\hline & $(0.108)$ & $(0.109)$ & $(0.109)$ & $(0.109)$ & $(0.268)$ & $(0.267)$ & $(0.305)$ & $(0.264)$ \\
\hline \multirow[t]{2}{*}{ Liquidity bk } & -0.547 & -0.337 & -0.333 & -0.462 & -0.387 & 0.051 & 0.970 & -0.116 \\
\hline & $(0.482)$ & $(0.486)$ & $(0.486)$ & $(0.485)$ & $(1.062)$ & $(1.044)$ & $(1.249)$ & $(1.042)$ \\
\hline Pseudo R2 & 67,509 & 67,509 & 67,509 & 67,509 & 25,309 & 25,309 & 25,309 & 25,309 \\
\hline Observations & 0.072 & 0.073 & 0.073 & 0.072 & 0.034 & 0.051 & 0.051 & 0.056 \\
\hline
\end{tabular}


Figure 1: Total Share of Lender Types in Term Loans

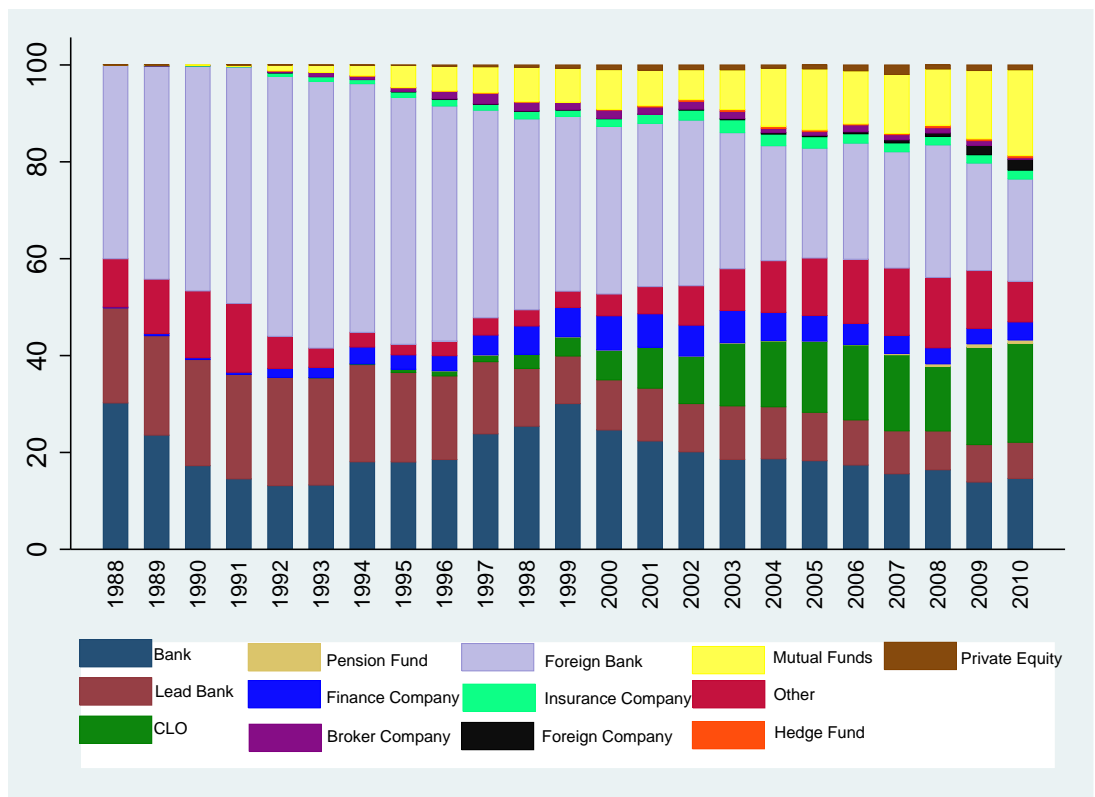

Note: This graph shows the percentage contribution of each lender type in the total term loan amount. We sum up the amount of all term loans originated by a given lender type per year and divide it by the total term loan amount.

Figure 2: Total Share of Lender Types in Credit Lines

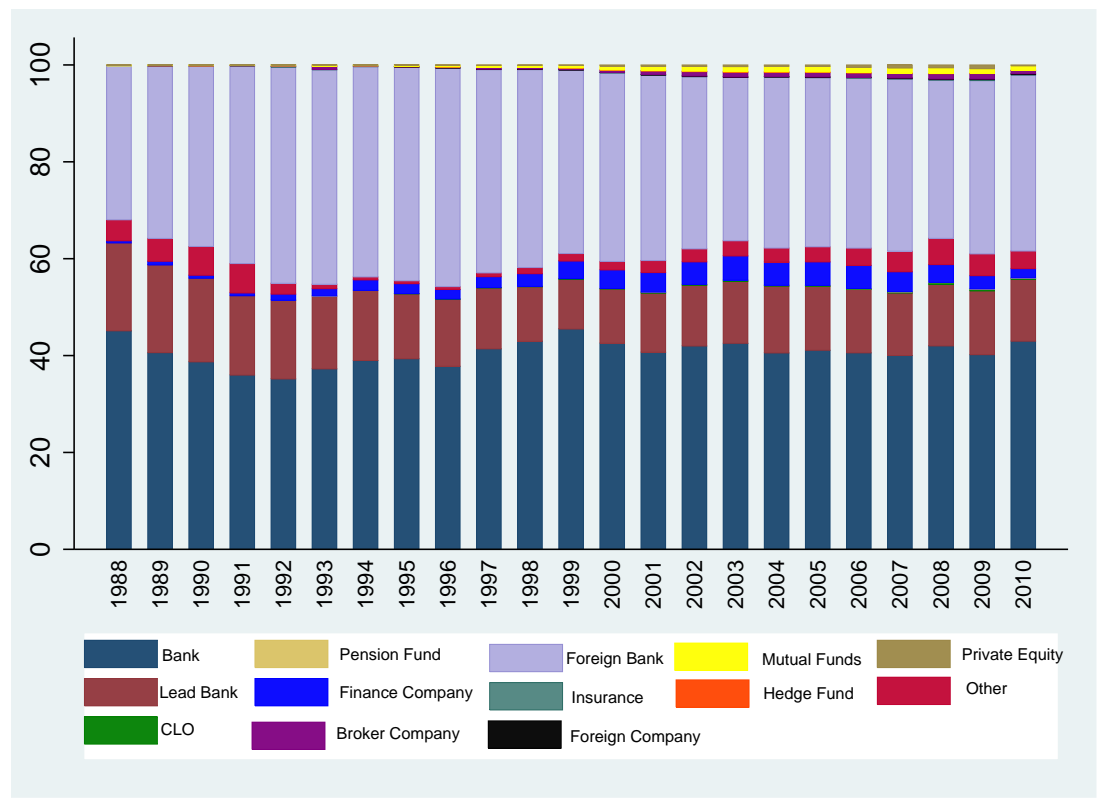

Note: This graph shows the percentage contribution of each lender type in the total credit line amount. We sum up the amount of all credit lines originated by a given lender type per year and divide it by the total credit line amount. 


\section{Figure 3: CLOs in Term Loans}

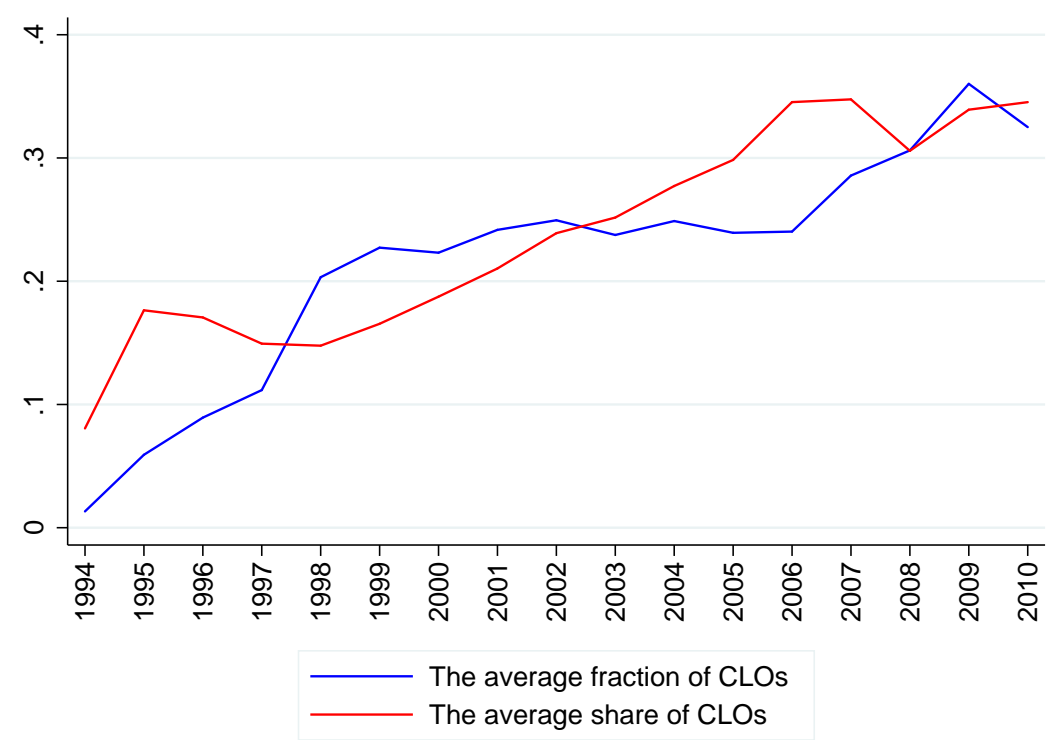

Note: The red line shows the average CLO share, conditional on CLO presence. The blue line shows the fraction of loans with (at least one) CLOs.

\section{Figure 4: CLOs and their Relationships with Lead Banks}

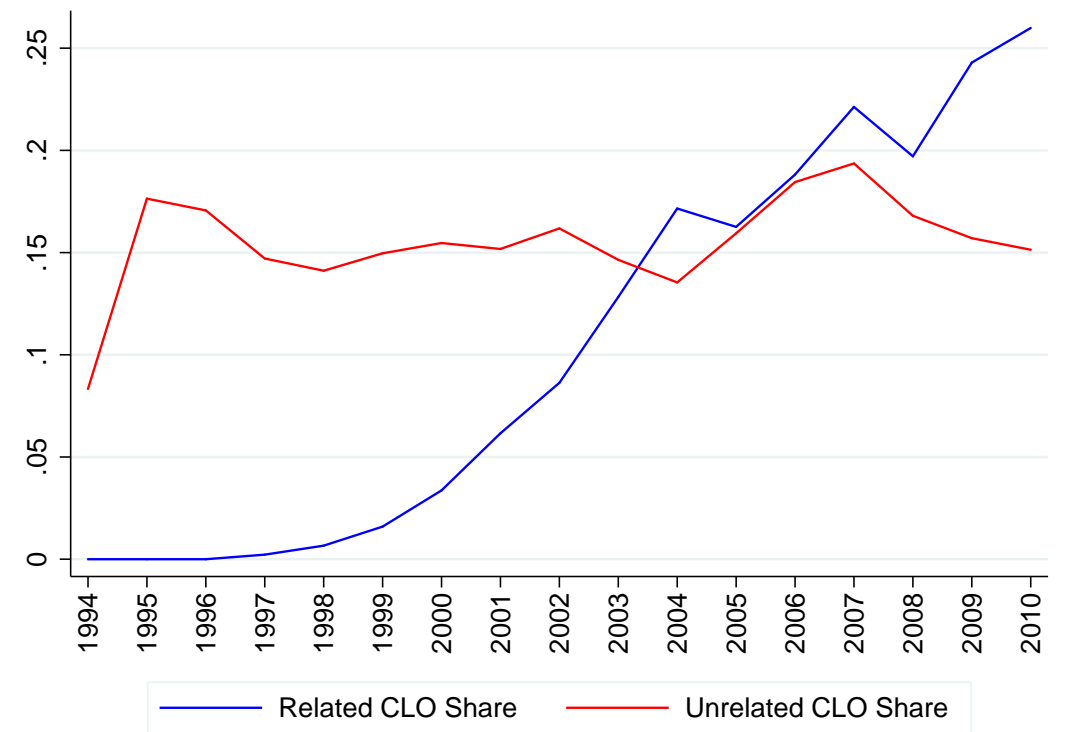

Note: Related $C L O$ Share is the average share of those CLOs related to lead banks through underwriting services in term loans. Unrelated CLO Share is the average CLO share unrelated to lead banks through underwriting services. The series are calculated for syndicates with CLOs. 
Figure 5: The Evolution of Syndicate Structure

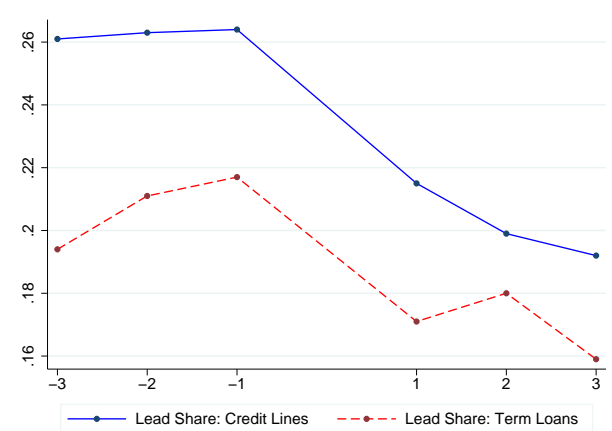

(a) Lead share

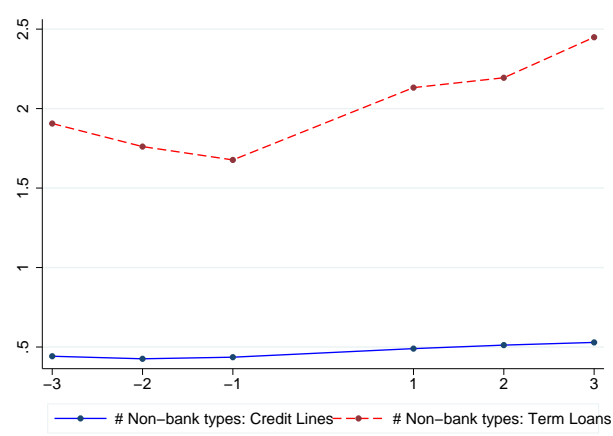

(c) \# Non-bank types

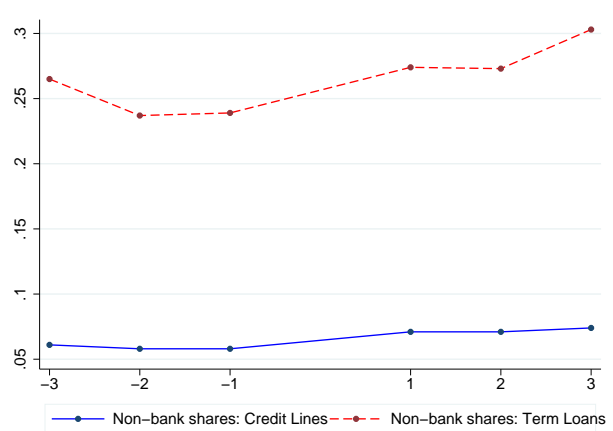

(b) Non-Bank Shares

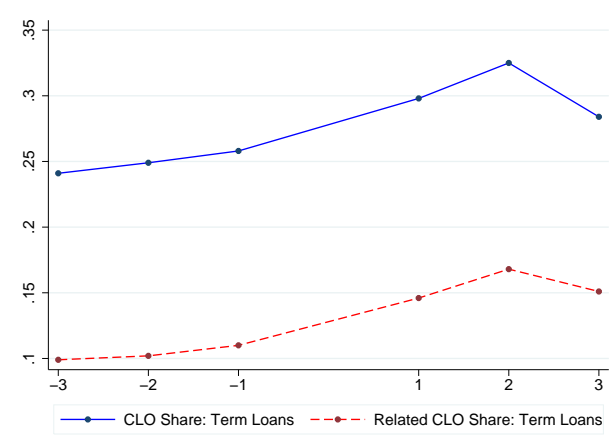

(d) CLO/Related Shares 
Figure 6: Logit Margin Plots for Credit Lines and Term Loans

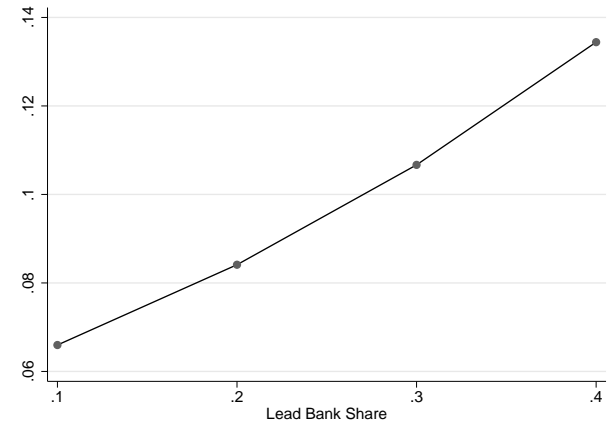

(a) Credit Lines: Lead Bank Share

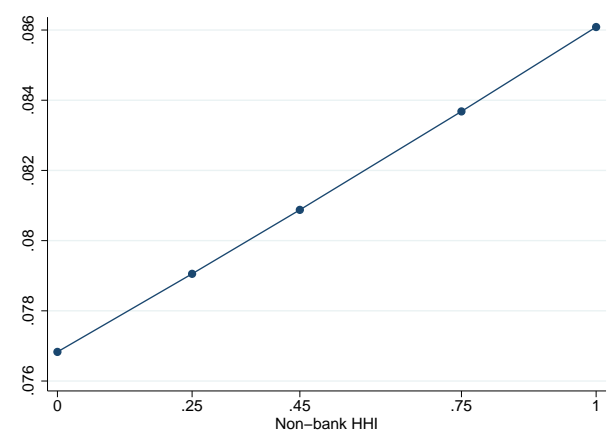

(c) Credit Lines: Non-Bank HHI

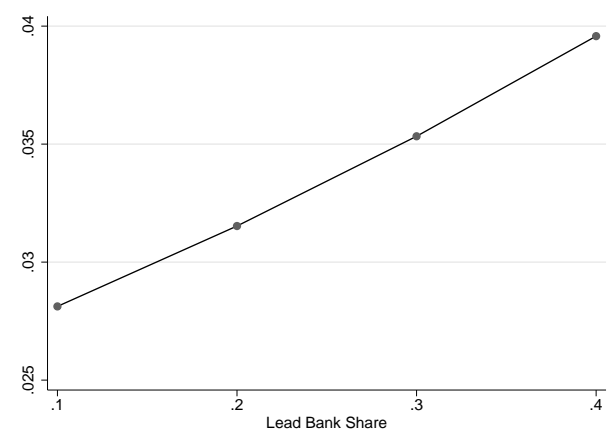

(e) Term Loans: Lead Bank Share

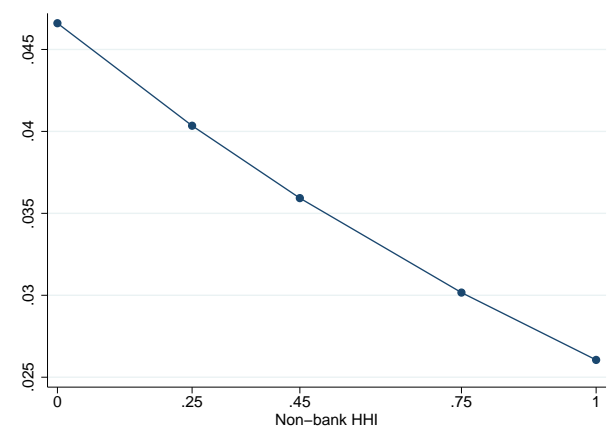

(g) Term Loans: Non-Bank HHI

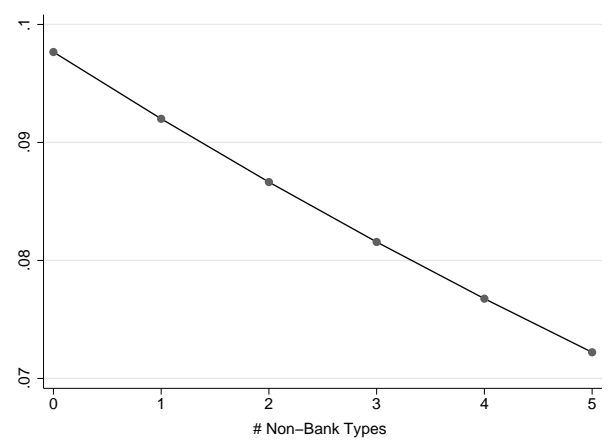

(b) Credit Lines: \# Non-Bank Types

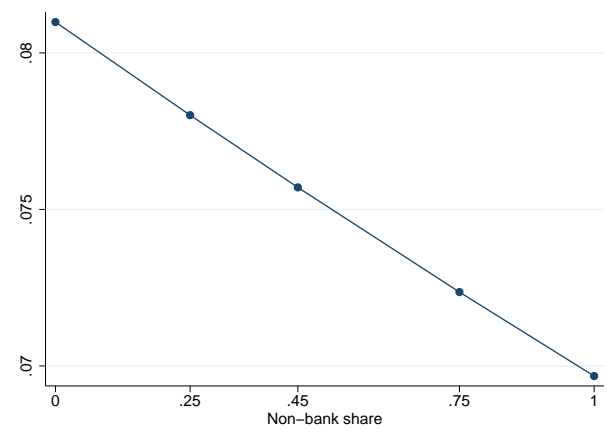

(d) Credit Lines Non-Bank Share

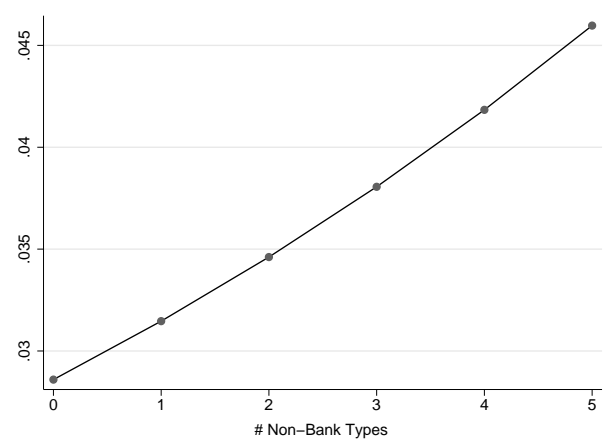

(f) Term Loans: \# Non-Bank Types

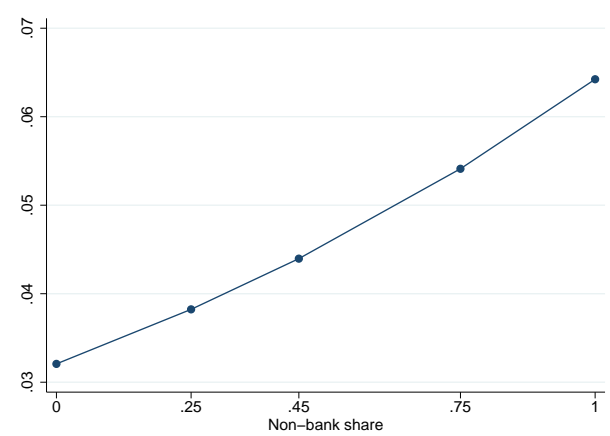

(h) Term Loans: Non-Bank Share 
Figure 7: Term Loan Growth by Lender Type Before and After a Renegotiation

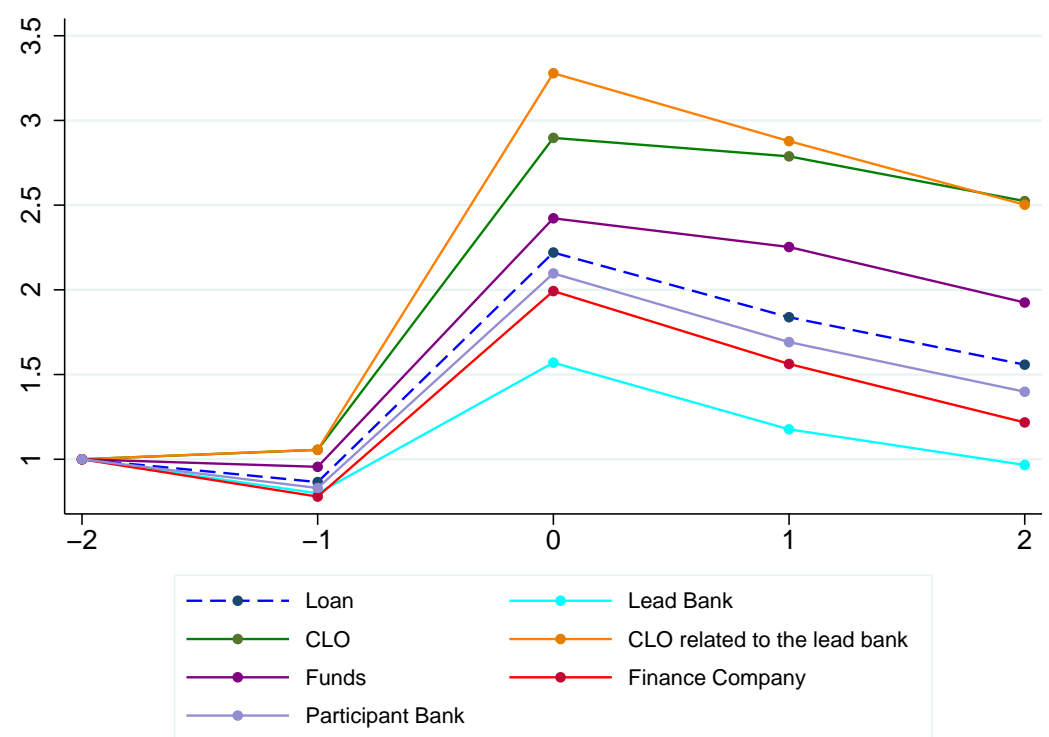

Note: This graph shows the growth in total lender amounts before $(-2,-1)$ and after $(1,2)$ renegotiations. The total lender amount is scaled by the respective total lender amount two years before the renegotiation. The renegotiation occurs between period -1 and 0 .

Figure 8: The Sum of Shares Before and After a Renegotiation

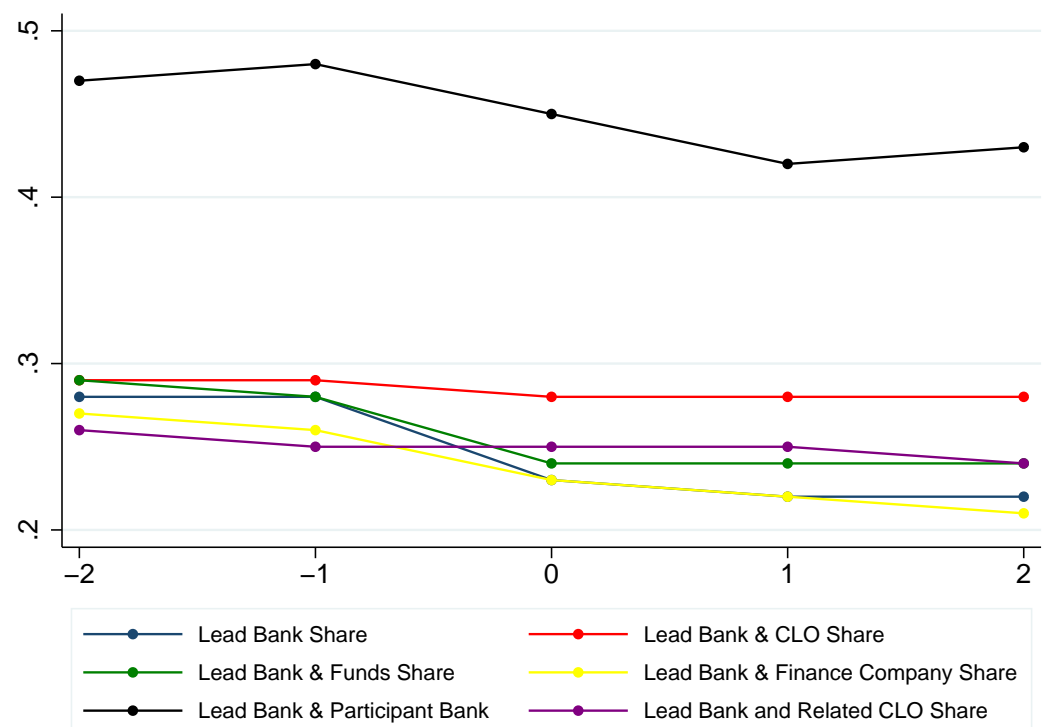

Note: This graph shows the sum of average lead and different lender type shares before $(-2,-1)$ and after $(1,2)$ renegotiations. The renegotiation occurs between period -1 and 0 . 


\section{Appendix 1: Definition of Variables}

Borrower rating takes one if the borrower is rated by a credit-rating agency.

Broker company $d$ takes one if at least one lender is classified as a broker company.

Broker company share is the sum of percentage shares of all broker lenders in a loan.

Credit line equals one if the loan is a credit line (revolving credit, revolving credit converting to term loan, line of credit, commercial letter of credit, revolving credit, standby letter of credit and demand loan).

$C L$ drawdown ratio is the ratio of credit line drawdown to total available credit. The ratio takes the value one if a loan is classified as a term loan.

$C L O d$ takes one if at least one lender is classified as a collateralized loan obligation (CLO).

$C L O$ share is the sum of shares for all CLO lenders in a given loan.

Capital $b k$ is the annualized ratio of quarterly equity over quarterly risk-weighted assets.

Deposits $b k$ is the annualized ratio of quarterly deposits over quarterly assets.

Finance company $d$ takes one if at least one lender is a finance company.

Finance company share is the percentage share of all finance companies in a loan.

Funds $d$ takes one if at least one lender is defined as a mutual, hedge or a pension fund.

Funds share is the sum of percentage shares for mutual, hedge and pension fund shares in a given loan.

Insurance company $d$ takes one if at least one lender is an insurance company.

Insurance company share is the sum of percentage shares of all insurance companies in a given loan.

$L$ assets $b k$ is the natural log of yearly bank assets in hundreds of millions.

Liquidity $b k$ is the annualized ratio of quarterly cash and short-term investments to quarterly risk-weighted assets.

Lead bank share is the percentage share of the lead bank in a loan.

Ln initial loan amount is the amount of the loan at the time of origination.

Loan age is year of the loan. In the regressions, it is a set of dummy variables.

Loan rating is the rating provided by the regulator. It is the percentage of the loan that obtains an investment-grade rating.

Maturity left is the difference between the loan maturity year and the current loan year.

$M \mathscr{E} A$ is an indicator variable that takes one if the loan is used for financing merger and acquisition deals and zero otherwise.

Non-bank share is the sum of shares for all lenders except for lead and participant banks.

Non-bank HHI is the Herfindahl-Hirschman index of the non-bank lender shares. It is the sum of the squares of all non-bank share types. For the purpose of that measure, nonbank shares are defined as the fraction of loan amount held by each non-bank lender divided by the total non-bank amount in a loan. Higher values are associated with greater concentration. 
\# Non-bank types is the sum of different lender types in a loan.

Other lender $d$ takes one if at least one lender is left unclassified.

Other lender share is the sum of percentage shares of unclassified lenders.

Profitability $b k$ is the annualized ratio of quarterly bank net income before taxes over quarterly risk-weighted assets.

Participant bank share is sum of percentages of participant banks and foreign banks.

Real estate is an indicator variable that takes one if the loan is used for financing real estate loans and zero otherwise.

Related CLO share is the sum of CLO shares that have the lead bank as an underwriter.

Renegotiation takes one if the loan amount increases compared with the previous year and there is a change in maturity and zero otherwise.

Unrelated CLO share is the sum of CLO shares that are not related to the lead bank through underwriting services.

Working capital is an indicator variable that takes one if the loan is used for working capital and zero otherwise.

Zero lead is a dummy variable that takes one if the lead share has a zero share in the loan. 


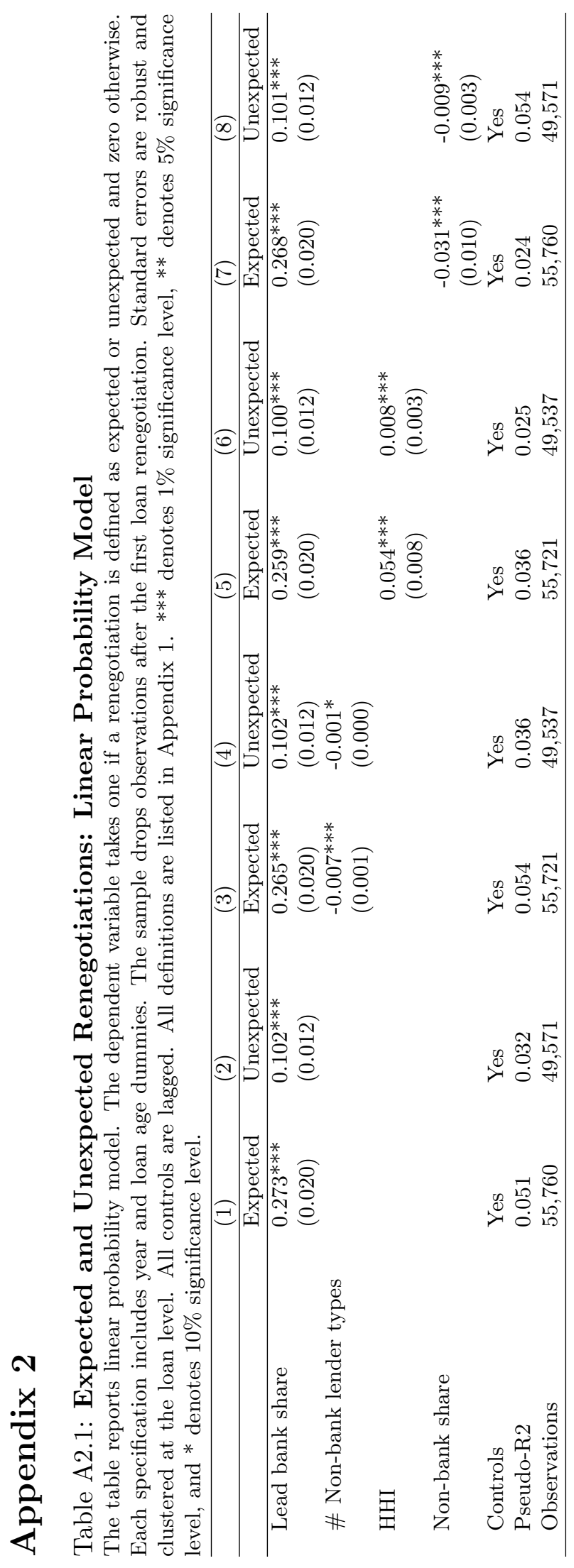


Table A2.2: CLO Relationships: Bank Fixed Effects

The table reports bank fixed effect logit regression estimates. The dependent variable takes one if a loan is renegotiated in a given year and zero otherwise. Each specification includes year and loan age dummies. All definitions are listed in Appendix 1. *** denotes $1 \%$ significance level, ${ }^{* *}$ denotes $5 \%$ significance level, and $*$ denotes $10 \%$ significance level.

\begin{tabular}{|c|c|c|c|}
\hline & (1) & $(2)$ & $(3)$ \\
\hline & & Pre-2000 & Post-2000 \\
\hline \multirow[t]{2}{*}{ Lead bank share } & $1.857^{* * *}$ & $1.502^{* * *}$ & $2.104^{* * *}$ \\
\hline & $(0.301)$ & $(0.428)$ & $(0.427)$ \\
\hline \multirow[t]{2}{*}{ Related CLO share } & $1.894^{* * *}$ & 1.454 & $2.071^{* * *}$ \\
\hline & $(0.481)$ & $(1.895)$ & $(0.532)$ \\
\hline \multirow[t]{2}{*}{ Unrelated CLO share } & 0.773 & 0.663 & 0.543 \\
\hline & $(0.535)$ & $(1.399)$ & $(0.786)$ \\
\hline \multirow[t]{2}{*}{ CLO d } & 0.094 & -0.043 & 0.203 \\
\hline & $(0.155)$ & $(0.309)$ & $(0.188)$ \\
\hline \multirow[t]{2}{*}{ Funds d } & -0.036 & 0.012 & -0.116 \\
\hline & $(0.156)$ & $(0.293)$ & $(0.189)$ \\
\hline \multirow[t]{2}{*}{ Finance company d } & 0.061 & 0.012 & 0.025 \\
\hline & $(0.133)$ & $(0.272)$ & $(0.155)$ \\
\hline \multirow[t]{2}{*}{ Broker company d } & 0.141 & 0.322 & 0.157 \\
\hline & $(0.149)$ & $(0.340)$ & $(0.173)$ \\
\hline \multirow[t]{2}{*}{ Insurance company d } & 0.021 & 0.237 & -0.132 \\
\hline & $(0.156)$ & $(0.337)$ & $(0.178)$ \\
\hline \multirow[t]{2}{*}{ Other lender d } & 0.049 & -0.003 & 0.153 \\
\hline & $(0.113)$ & $(0.223)$ & $(0.137)$ \\
\hline \multirow[t]{2}{*}{ Funds share } & 0.273 & 0.448 & -0.040 \\
\hline & $(0.437)$ & $(0.638)$ & $(0.640)$ \\
\hline \multirow[t]{2}{*}{ Finance company share } & 0.366 & 0.667 & 0.492 \\
\hline & $(0.608)$ & $(1.263)$ & $(0.701)$ \\
\hline \multirow[t]{2}{*}{ Broker company share } & -0.650 & -0.458 & -1.912 \\
\hline & $(1.158)$ & $(1.701)$ & $(1.901)$ \\
\hline \multirow[t]{2}{*}{ Insurance company share } & 0.109 & -0.589 & 0.441 \\
\hline & $(0.953)$ & $(1.702)$ & $(1.216)$ \\
\hline \multirow[t]{2}{*}{ Other lender share } & 0.179 & -0.619 & 0.285 \\
\hline & $(0.343)$ & $(0.870)$ & $(0.379)$ \\
\hline \multirow[t]{2}{*}{ Ln initial loan amount } & $-0.163^{* * *}$ & $-0.109^{* *}$ & $-0.187^{* * *}$ \\
\hline & $(0.034)$ & $(0.055)$ & $(0.044)$ \\
\hline \multirow[t]{2}{*}{ Loan rating } & $0.005^{* * *}$ & $0.004^{* *}$ & $0.005^{* * *}$ \\
\hline & $(0.001)$ & $(0.002)$ & $(0.001)$ \\
\hline \multirow[t]{2}{*}{ Maturity left } & $0.187^{* * *}$ & $0.150^{* * *}$ & $0.244^{* * *}$ \\
\hline & $(0.013)$ & $(0.020)$ & $(0.019)$ \\
\hline \multirow[t]{2}{*}{ Working capital } & 0.095 & 0.271 & -0.023 \\
\hline & $(0.098)$ & $(0.169)$ & $(0.125)$ \\
\hline \multirow[t]{2}{*}{$\mathrm{M} \& \mathrm{~A}$} & -0.010 & 0.106 & -0.090 \\
\hline & $(0.088)$ & $(0.134)$ & $(0.120)$ \\
\hline Real estate & -0.060 & -0.236 & 0.088 \\
\hline & $(0.113)$ & $(0.184)$ & $(0.151)$ \\
\hline Borrower rating & 0.150 & 0.217 & 0.142 \\
\hline & $(0.112)$ & $(0.198)$ & $(0.137)$ \\
\hline Profitability bk & $98.947 * * *$ & $93.784^{*}$ & $95.044^{* * *}$ \\
\hline & $(22.910)$ & $(49.720)$ & $(29.414)$ \\
\hline Capital bk & 1.588 & -5.670 & 2.718 \\
\hline & $(4.105)$ & $(8.871)$ & $(5.374)$ \\
\hline $\mathrm{L}$ assets bk & -0.029 & -0.124 & -0.100 \\
\hline & $(0.074)$ & $(0.167)$ & $(0.124)$ \\
\hline Deposits bk & -0.439 & $-2.765^{* *}$ & -0.138 \\
\hline & $(0.734)$ & $(1.316)$ & $(1.252)$ \\
\hline Liquidity bk & -3.401 & 1.070 & $-5.615^{*}$ \\
\hline & $(2.073)$ & $(3.211)$ & $(3.150)$ \\
\hline Observations & 22,498 & 9,063 & 13,128 \\
\hline Pseudo-R2 & 0.058 & 0.047 & 0.077 \\
\hline
\end{tabular}




\section{Appendix 3: Typical Structure of a CLO Deal}

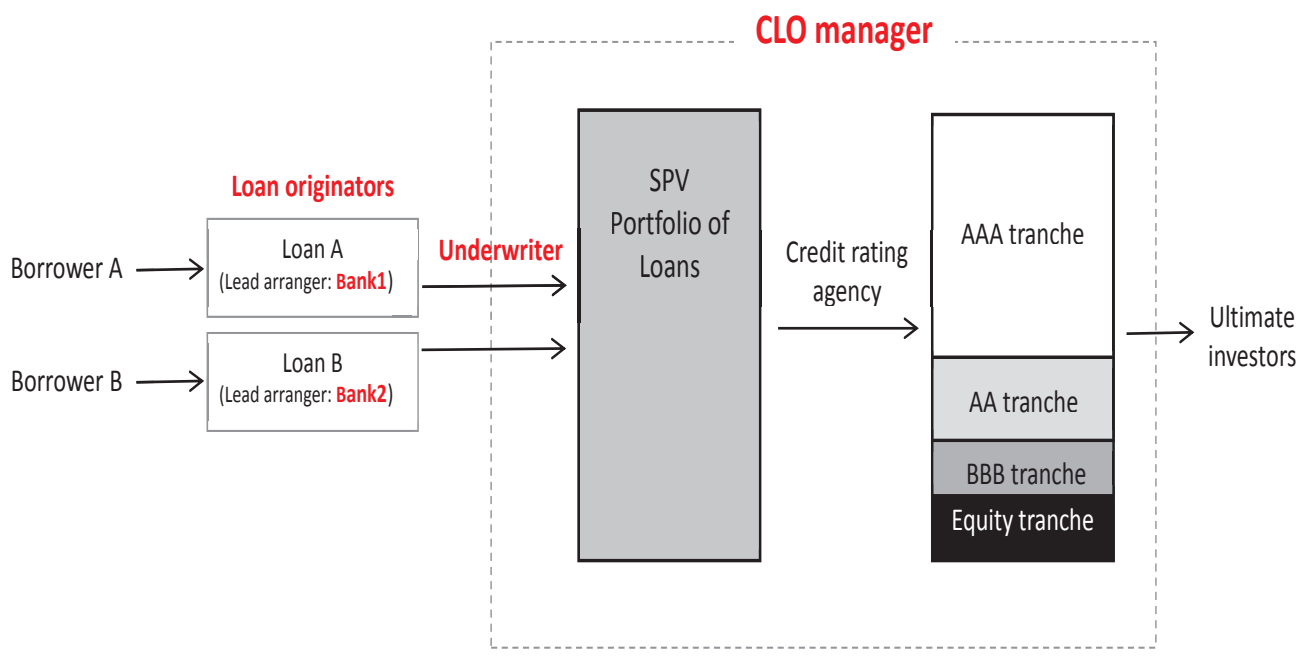

Source: Benmelech et al. (2012).

What is a CLO? Collateralized loan obligations are a type of securitization vehicle backed by a pool of leveraged loans that are actively managed via a bankruptcy-remote special-purpose vehicle (SPV). Leveraged loans refer to syndicated bank loans issued to below investment grade corporations. A CLO raises money primarily by issuing its own bonds and then reinvests those proceeds into a portfolio of loans. Similar to mutual funds, CLO pools receive funding from a variety of investors so that it can give each investor greater risk/reward diversity than by investing directly in leveraged loans. Investors purchase specific tranches with specific seniority and priority of payment.

Life cycle of a CLO. The life cycle of a CLO includes a ramp-up period, followed by reinvestment, amortization, and non-call periods. Upon CLO issuance, the proceeds are used to purchase pools of leveraged loans. During the warehousing period the CLO manager has several months to ramp up and optimize purchases. After the collateral is fully ramped up, CLO managers can still reinvest during the reinvestment period, within certain parameters required in the prospectus. When the deal is out of the reinvestment period, it will amortize according to the cash-flow waterfall priority from the top (AAA tranches) to the bottom tranches (Equity tranche). A CLO has two to three years of a non-call period and then it can be called by the ownership tranche.

CLO managers. The role of the CLO manager is to actively buy, sell and manage the loan collateral to maximize equity returns while minimizing defaults to ensure that senior debt gets paid in full. The CLO manager has to maintain par values on the loan collateral by purchasing loans below par. The manager's ability to avoid default losses and maintain a high level of income from the collateral pool is paramount to making the structure work. The CLO manager is compensated with three types of fees: senior (paid before the interest on senior tranches); junior (paid if the senior and mezzanine tranches receive their interest claims and collateral tests are met); and incentive (CLO equity returns exceed a pre-specified threshold) fees. 